\title{
Mobil Reklamcılıkta Müşteri Memnuniyeti: Sosyal Medya Kullanıcıları Üzerinde Bir Araştırma"
}

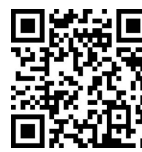

Sabiha KILIÇ** Ahmet Emin ÜNVER ${ }^{* * *}$

\section{$\ddot{\mathbf{O z}}$}

Mobil teknolojinin gelişmesi ve mobil araçların reklam kanalları içerisinde kullanılmasıyla birlikte, firmaların kaliteli hizmet sunma ve müşteri memnuniyeti să̆lama üzerine yaptıkları çalışmalar da gelişme göstermiştir. Bir yandan teknoloji gelişirken diğer yandan tüketicilerin istek, ihtiyaç ve beklentileri de değişime uğramıştır. Tüketiciler artık en kaliteli ve kendilerini en çok memnun edecek ürün ve hizmetleri elde etmek için çaba sarf etmektedir. Günümüzün rekabet şartları tüketicilere zaman ve mekân sınırı olmadan ulaşılmasını gerektirmektedir. Mobil araçların tüketicilere doğrudan, mekân ve zaman sınırı olmadan ulaşılmasını mümkün kılan bir yol olduğu düşünüldüğ̈̈nde, firmaların bu reklam kanalını pazarlama etiği çerçevesinde etkin ve verimli bir şekilde kullanmaları hem daha kaliteli hizmet sunabilme hem de müşteri memnuniyeti sağlayabilme yolunda firsatlar sunmaktadır. Bu çalışmada, mobil reklamcılıkta müşteri memnuniyeti ile bireysel müşteri hizmet kalitesi ve algılanan müşteri memnuniyeti değişkenleri arasındaki ilişkiler değerlendirilmiştir. Bireysel müşteri hizmet kalitesi ve algılanan müşteri memnuniyeti değişkenlerinin, mobil reklamcılıkta müşteri memnuniyeti ile ilişkisini belirleyebilmek amacıyla Facebook, Twitter ve Linkedin kullanıcıları üzerinde anket çalışması yapılmıştır. Anket verileri SPSS istatistik paket programı ile analiz edilmiştir.

Anahtar Kelimeler: Mobil Reklamcılık, Müşteri Memnuniyeti, Hizmet Kalitesi. Jel Kodları: M31, M37.

\section{Customer Satisfaction in Mobile Advertising: A Case Study on Social Media Users}

\begin{abstract}
With the development of mobile technology leading to the use of mobile tool in the advertising channels, the studies undertaken by the companies to provide services as well as to ensure customer contentment have recorded a considerable development. While technology developed from one hand; the wishes, needs and expectations of customers have also changed on another. In order to obtain the products with top quality and services corresponding to them best, people are now making all possible efforts. As the competencies of today allow companies to reach out broader masses without the limitations of time and space, operating the advertising channels effectively and efficiently in the framework of marketing ethics therefore constitutes cruciality in providing service and ensuring customer contentment. In this study, threads related to advertising, service quality and customer contentment are examined. In order to demonstrate the correlation between individual customer service quality and customer contentment, the questionnaire is carried out among the Facebook, Twitter and Linkedin users. The survey data is processed on statistical package software and findings are evaluated.
\end{abstract}

Keywords: Mobile Advertising, Customer Contentment, Service Quality.

Jel Codes: M31, M37.

\footnotetext{
* Bu çalışma Hitit Üniversitesi Sosyal Bilimler Enstitüsü İşletme Anabilim Dalı'nda tamamlanan "Mobil Reklamcılıkta Bireysel Müşteri Hizmet Kalitesi ve Müşteri Memnuniyeti İlişkisine Dair Ampirik Bir Çalışma" başlıklı Yüksek Lisans tezinden üretilmiştir.

** Doç. Dr., Hitit Üniversitesi, İ̈BF, İşletme Bölümü, skilic19@hotmail.com ORCID: http://orcid.org/0000-0002-0906-4567

${ }^{* * *}$ Makim Makine Teknolojileri A.Ş. ahmeteminunver@hotmail.com ORCID: http://orcid.org/0000-0002-0602-9512
} 


\section{Giriş}

Mobil telefonların reklam kanalları içerisinde yer edinmesiyle birlikte, pazarlama ve reklam alanlarında önemli değişimler yaşanmıştır. Küreselleşmenin ve teknolojideki büyük ilerlemenin sunduğu yeni pazarlama ve reklam olanakları, bireylerdeki istek, ihtiyaç ve beklentilerdeki değişme ve farklılaşma, işletmelerin kaliteli hizmet sunabilme ve tüketicilerde memnuniyet yaratabilme çabalarını arttırmalarını gerekli kılmıştır. Yaşanan hızlı değişime ve zor rekabet koşullarına adapte olmaya çalışan işletmeler için pazarlama ve reklam kampanyalarında kaliteli hizmet sunmak ve müşteri memnuniyeti sağlamak önde gelen hedefler arasında yer almaktadır (Özgüven, 2013).

Çalışmada bireysel müşteri hizmetleri olarak ifade edilen sesli reklam aramaları, mobil reklamcılık kapsamında firmaların reklam kampanyalarını mobil telefonlar aracılığıyla müşterilerine ulaştırmakta kullandıkları bir mobil reklam kanalıdır. Firmalar mobil reklam aramaları gerçekleştirerek müşterilerine doğrudan reklam kampanyaları sunabilmektedirler. Mobil reklam aramaları, firmalara tüketicilerin zamanına, bulunduğu konuma ve tüketici önceliklerine göre kişiselleştirilmiş reklam kampanyaları sunmayı sağlaması nedeniyle önem taşımaktadır. Mobil reklam aramalarında hizmet kalitesi düzeyini etkileyen birçok unsur bulunmaktadır. Bunların başında reklam personelinin reklam hizmetini sunuş biçimi, müşterilere karşı ilgili ve anlayışlı olması, reklam aramalarının müşteri beklentilerini, ihtiyaç ve isteklerini karşılama potansiyeli ve aramaların müşteriye uygun zaman dilimlerinde gerçekleştirilmesi sayılabilir (Reyck ve Degraeve, 2003).

Bu çalışma, mobil reklamcılıkta bireysel müşteri hizmet kalitesi ile müşteri memnuniyeti arasındaki ilişkiyi değerlendirmeyi amaçlamaktadır. Bu amaç kapsamında, hizmet kalitesi unsurlarındaki iyileşmelerin hizmet kalitesi düzeyini arttırabileceği, müşteri memnuniyetini etkileyen memnuniyet boyutlarındaki iyileşmelerin de müşteri memnuniyeti düzeyini olumlu yönde etkileyebileceği varsayılmaktadır.

\section{Mobil Reklamcılık Kavramı}

İşletmelerin mal, hizmet ve markaları ile ilgili yeni bilgileri potansiyel müşterilerine ulaştırabilmesi için hedef müşterileriyle iletişim kurması gerekmektedir. $\mathrm{Bu}$ iletişim gerçekleştirildiğinde hem doğru hedef kitleye etkin bir biçimde ulaşılabilmekte, hem de pazarlama kampanyalarının daha etkili, doğrudan ve geri dönüşü yüksek bir yapıda hazırlanabilmesi sağlanabilmektedir. $\mathrm{Bu}$ nedenle işletmelerin en çok önem verdikleri konulardan birisi, yer ve zaman kısıtları olmadan potansiyel müşterileriyle iletişim kurmaktır. Mobil telefonların bu ihtiyacı kısıtlı da olsa diğer tutundurma araçlarına göre daha etkin bir şekilde karşılaması, mobil telefonları işletmeler için önemli hale getirmiştir (Barutçu ve Göl, 2009:25).

Günümüzde insan hareketliliğinin artması ve insanların zaman ve yer hassasiyetine sahip olması nedeniyle geleneksel medya araçları hedef müşteri gruplarına ulaşmada yetersiz kalmaktadır. Mobil reklam, işletmelerin mobil iletişim araçları üzerinden kablosuz interaktif medyayı kullanarak, mevcut ve potansiyel müşterilerine ulaşmalarını ve onlara kişiselleştirilmiş bilgilerle mal, hizmet ve fikirler sunmalarını sağlayan bir yaklaşımdır (Özgüven, 2013:123). De Reyck ve Degrave (2003)'e göre mobil reklamcilık, doğru tanımlanmış potansiyel müşterilere kısa mesajlar ile ulaşılması hedeflenerek reklama cevap verme oranının artırılmasıdır. Gerçek zamanlı alışveriş yapan müşterilere gönderilen mobil reklamlar, reklamın uygulanma şansının arttırılmasını sağlayabilmektedir (De Reyck ve Degrave, 2003:509). Mobil pazarlama derneği ise, mobil reklamcılığı tüketiciye mobil kanallar 
üzerinden ulaşılan her türlü reklam, pazarlama ve promosyon aktivitesi olarak ifade etmektedir(http://www.mmaglobal.com/). Kısaca mobil reklam, mobil araçları kullanan reklamdır denilebilir (Kıraç, 2012:24).

Etkileşimi ön plana çıkarma ve interaktif kullanıma uygun olma, mobil reklamcılığın en temel karakteristiklerinden biridir. Mobil reklamcılık uygulamalarında tüketiciler, daha aktif bir rol üstlenmektedir ve mobil kanallar üzerinden kampanyaya katılmaları yönünde teşvik edilmektedirler. Mobil iletişim platformlarının en önemli avantajlarından bir diğeri de tüketicilerin kolaylıkla ve hızlı bir biçimde geribildirimde bulunmasına izin vermesi ve bu sayede geri dönüş oranının yükselmesine katkıda bulunmasıdır (Dağtaş vd., 2013:136).

Mobil reklamın geniş çaplı faaliyetleri kapsaması nedeniyle somutlaştırılıp açıklanması zordur. Bu faaliyetler, mobil reklamın diğer web sayfalarının içine yerleştirilerek, markaların görsel olarak görünmesini sağlaması, SMS ve MMS, Lokasyon temelli mobil pazarlama, mobil uygulamalar, mobil pazarlama araştırması, TV, radyo ve baskı ile yapılan offline pazarlama, web sitelerinde ve e-mail ile yapılan online pazarlamadır (Özgüven, 2013:125).

Mobil reklam, mobil reklamların sahip oldukları özelliklere göre dört gruba ayrılmaktadır. Bunlar, SMS (Short Message Service-Kısa Mesaj Servisi), MMS (Multimedia Messaging Service-Çoklu Ortam Mesajlaşma), ve Bluetooth ve Bireysel Müşteri Hizmetleridir.

SMS, düz metinden oluşan kısa mesajların mobil telefon kanalı üzerinden gönderilip alınabilmesini sağlayan, GSM iletişim sistemi içinde standart haline gelen bir sistemdir. SMS'de mesajlar GSM şebekeleri aracılığıyla gönderilmektedir. Gönderilen mesajların büyüklüğü, 140 byte ya da 160 karakter ile sınırlıdır. Mesaj gönderme sürecinde gönderici ve alıcı doğrudan sesli olarak iletişime geçmemektedirler. Gönderilen mesajların genellikle tamamı, alıcıya ulaşmaktadır. Mesaj gönderme-alma, şirketler ve müşteriler arasında hizmet ve geri bildirimi geliştirmektedir. Metin mesajı aynı zamanda kişilerarası iletişimde de oldukça popülerdir (Güzeler, 2010:41).

MMS, görüntülü, yazılı, sesli ve video içerikli mesajlar gönderilmesine imkân sağlayan bir sistemdir. MMS aracılığıyla reklamlar, tüketicilere sadece metinle ulaştırılmamakta, uygulamada görsel ve işitsel unsurlar da kullanılmaktadır. MMS, SMS'in sağladığı tüm avantajlara sahip olmanın yanı sıra kısa mesaj kavramına renkli resimler, animasyonlar, ses ve video klipleri ile yeni ve çok daha zengin bir boyut katmaktadır. Ayrıca SMS gibi kişisel iletişim, yüksek müşteri sadakati, esnek zamanlama, kitleyi sınıflandırabilme imkânı, takip olanağı ve yüksek geri dönüşüm oranı sağlamakta; ses, renk ve hareket ile yaratıcılık sunmaktadır. Bu uygulamanın en büyük dezavantajlarından biri; MMS reklamlarının teknik açıdan birçok telefon tipi için uygun olmasına rağmen, 100 kilobayttan büyük MMS reklamlarının eski model cep telefonlarına gönderildiğinde reklam kalitesinin düşmesi ya da reklamın hiç görüntülenememesidir. Bunun yanı sıra, bazı operatörler arasında MMS gönderiminin mümkün olmaması da uygulamada sorunlar yaratmaktadır.Ayrıca ufak ekranlarda MMS için etki kaybı söz konusudur (Dağtaş vd., 2013, 138).

İşletmelerin tüketicilere ulaşmasını sağlayan önemli kanallardan biri de lokasyon tabanlı mobil uygulamalardan biri olan bluetooth reklamlarıdır. Kablo bağlantısını ortadan kaldıran ve kısa mesafe radyo frekansı (RF) teknolojisi olan bluetooth; kablolu bağlantılara alternatif olarak geliştirilen radyo dalgaları vasıtasıyla, kısa mesafede yüksek hızda veri aktarımı sağlayan kablosuz iletişim sistemidir. İşletmeler bu uygulamayla mağaza ve alışveriş merkezi gibi belirli bir mekâna yakın olan tüketicilere bluetooth sistemi ile mesaj göndermektedirler. Örneğin, tüketiciler bir mağazanın yanından geçerken bluetooth sistemi devreye girmektedir ve tüketicilere yeni ürünlerle ilgili bilgi gönderilmektedir. Cep telefonundaki bluetooth 
uygulaması açık olan tüketicilere, reklam veren tarafından, gönderilen mesajı kabul edip etmediği sorulmaktadır. Tüketici mesajı almayı kabul ettiği takdirde, mesaj tüketiciye iletilmektedir (Dağtaş vd., 2013, 140).

Doğrudan pazarlama uygulamaları içerisinde yer alan telefon ile pazarlama ve satış yöntemi, son yıllarda mobil reklamcılık alanında da kullanılmaya başlanmıştır. Çalışmada, cep telefonu üzerinden çağrı yoluyla yapılan canlı reklam aramaları, bireysel müşteri hizmetleri olarak ifade edilmiştir. Bireysel müş̧eri hizmetlerinin yüz yüze olmayan kişisel pazarlama aracı olması, çok zaman almaması ve müşteri ile doğrudan kişisel bir iletişim sağlaması, bu kanalın mobil reklam türleri içerisinde yer edinmesini sağlamıştır (Tavmergen, 2002:80).

Bireysel müşteri hizmetleri, genellikle ofis, satış veya üretim birimi gibi bir noktadan müşterinin aranması şeklinde gerçekleşmekte ve reklam personeli ile müşteri arasında istenilen yer ve zamanda iletişim kurma imkânı sağlamaktadır. Ayrıca bireysel müşteri hizmetleri, iki taraflı iletişim kurma, modern teçhizat kullanımı, esneklik, iletişim başına düşen düşük maliyet, büyük kitlelere hitap edebilme, zaman tasarrufu sağlama ve kişiselleştirilmiş reklam hizmeti sunabilme bakımından önemli bir mobil reklam türüdür (Tavmergen, 2002:82).

Mobil reklam ve uygulamalarının başarılı olabilmesi için birtakım unsurların göz önünde bulundurulması gerekmektedir. Mobil reklamların yeni bir pazarlama kanalı olması nedeniyle ne tür kriterlerin bu mecrayı başarıya taşıyacağı da yeni yeni belirginleşmeye başlamıştır (Eru, 2013:153).

Mobil reklamın başarısında dikkate alınması gereken beş temel prensip, aşağıda açıklanmaktadır (Arslan ve Arslan, 2012:113):

- İzin Almak: Mobil kullanıcılara ne zaman ve ne tür reklam mesajları ya da reklam aramaları almak istedikleri konusunda kontrol imkânı sağlamaktır.

- Dĕ̆er Katmak: Mobil kullanıcıların mobil araçlarının değerli olduğunu hissetmelerini sağlamaktır.

- Ĕ̆lenceye ve Etkileşime Odaklanmak: Mobil kullanıcıların mobil araçlarında yer edinmektir.

- Ilgiye Odaklanmak: Mobil kullanıcıların ihtiyaçlarına ve isteklerine mobil araçları aracılığıla gerçek zamanlı cevap vermektir.

- Kolaylaştırmak: Mobil kullanıcıların mobil araçları tam olarak kullanabilmeleri için olgunlaşmaları gerektiğinden mobil araçların kullanımının kolaylaştırılması gerekmektedir.

Fuller (2005)'e göre tüketicilerin mobil reklamcılığa karşı olumsuz tutum içinde bulunmalarına neden olan faktörler sıklık, kontrol, gizlilik ve ilişkililiktir. Sıklık; tüketiciye sık sık gönderilen mesajların ve yapılan reklam aramalarının tüketicinin markaya ve işletmeye karşı olumsuz tutum içine girmesine neden olduğunu ifade etmektedir. Kontrol; tüketicinin mobil reklamı tekrar almak istemeyerek reklamcının kayıtlı isim listesinden çıkabilmesidir. Gizlilik; tüketici özel bilgilerinin haberi olmadan kullanılmadığından emin olmasıdır. İlişkililik; reklamın etkinliğinin kullanılan servisle ilişkili olmasıdır (Fuller, 2005; Özgüven, 2013:159).

Mobil reklamların başarılı olabilmesi için reklam içeriğinin -parasal teşvik, bilgi, eğlence gibi- hedef kitleye daha fazla fayda sağlayacak şekilde donatılması, müşterilere göre reklamların kişiselleştirilmesi gerekmektedir. Müşterilerin zamandan ve mekândan bağımsız olarak mobil telefonları devamlı yanlarında bulundurmaları nedeniyle reklam mesajları ve reklam aramaları en uygun zamanda ve sıklıkta yapılmalıdır. Mobil reklamların başarısında başka bir faktör, firmaların iyi bir veri tabanı oluşturmasıdır. Mobil reklamların geleneksel reklam kanallarında olduğu gibi herkesi hedef alması söz konusu olmadığından, firmaların 
reklam kampanyaları için müşterilerinin alışkanlıkları, istekleri, tercihleri ve ilgi alanları konusunda bilgi sahibi olmaları ve uygun müşteriye uygun reklam kampanyası sunmayı sağlayacak müşteri bilgi kanalı oluşturmaları gerekmektedir (Eru, 2013:154). Ayrıca hedef kitlenin kullandığ 1 mobil telefon özellikleri de başarı için önemlidir. Görüntülü reklamlar içeriği desteklemeyen telefonlara içerik gönderilmemeli, mobil telefonun özelliğine göre mesajların uzunluğu, süresi belirlenmeye çalışılmalıdır. Mobil reklamda sunulan mal ve hizmetler, kullanıcıların isteklerine ve konumlarına uygun olmalı, kişisel bilgilerin gizliliği konusunda tüketiciye güven verilmelidir (Özgüven, 2013:133).

Mobil reklamların başarısında hedef kitlenin de önemi büyüktür. Bu amaçla hedef kitlenin belirlenmesi ve kültürel değişkenlerin dikkate alınması gerekmektedir. Bugün cep telefonları tüm kültürlere çok hızlı bir şekilde nüfuz etmiş olsa da her kültürde kullanım amacı birbirinden farkl1lık göstermektedir. Kuzey Avrupa'da bireysellik daha ön planda olduğundan cep telefonu daha çok iletişim amacıyla kullanılmaktadır. Bu nedenle kısa mesaj göndermek daha yaygın haldedir. Güney Avrupa'da ise cep telefonu konuşmanın dışında internete bağlanmak amacıyla da kullanılır. Bu toplumda, sınıf farklılıkları daha belirgindir. Bu kültürel farklılıklar dikkate alındığında, işletmenin genel bir mesajı herkese göndermesi durumunda her kesimden aynı etkiyi alamayabilir (Özgüven, 2013:164). Aşağıdaki bölümde çalışmanın amacına uygun olarak hizmet kalitesi kavramı ayrıntılı olarak incelenmiştir.

\section{Hizmet Kalitesi Kavramı Literatür İncelemesi}

Hizmet kalitesi, hizmetin müşterinin hizmetten beklentilerini ne düzeyde karşıladığıdır (akt. Kenzhebayeva, 2012:23). Müşterinin hizmet sunandan beklentileri ile hizmet sunanın gerçek performansı arasındaki fark, hizmet kalitesini ortaya koymaktadır (Çatı ve Baydaş, 2008:241). Mükemmel hizmet kalitesinin sağlanabilmesi, müşterilerin ne istediği ile sunulan hizmet arasındaki ilişkinin iyi kurulmasına bağlıdır (Kenzhebayeva, 2012:23).

Hizmet kalitesi, işletmenin müşteri istek ve beklentilerini karşılayabilme yeteneği ve müşterinin tatmin edilmesidir. Müşterinin beklentileri, algılamasından daha yüksek seviyede ise, hizmet kalitesi algılaması düşük düzeylidir. Eğer algılama beklentileri karşılıyor ya da aşıyorsa, hizmet kalitesi algılaması yüksek düzeyli ve tatmin edicidir. Başka bir ifadeyle hizmet müşteri beklentisini karş1lıyor veya geçiyorsa hizmetin kalitesi iyi, tersi durumda hizmet kalitesi kötüdür (Aksu, 2010:25).

Hizmet kalitesi bir değerlendirmeyi ifade etmektedir. Tüketici, ürün ya da hizmeti almadan önce zihninde o hizmetlerle ilgili beklentiler oluşturmakta ve ürün ya da hizmeti kullandıktan sonra aldığı hizmet ile beklediği hizmeti karşılaştırmaktadır. Eğer tüketicinin aldığı hizmet beklediği hizmetten daha iyi ise hizmet kalitesini yüksek olarak değerlendirmektedir. Tersi durumda hizmet kalitesi düşük olmakta ve memnuniyetsizlik oluşmaktadır (Altunışık vd., 2007:176).

Hizmet kalitesi, müşteri beklentilerinin sürekli olarak karşılanmasıdır. İşletmelerin üstün hizmet sağlaması ve istenilen hizmet kalitesi düzeylerine ulaşabilmesi, yönetimin işletme içi ve dışı performans standartlarına uygun şekilde açıkça tanımlamış olduğu hizmet paketinin müşterilere süreklilik içerisinde sunulması ile mümkündür (Kenzhebayeva, 2012:21).

Hizmet kalitesi, müşterinin hizmeti satın aldıktan sonra o hizmetten sağladıklarının kendisinde meydana getirdiği duygulardır. Ayrıca hizmet kalitesi müşterinin hizmetten ne ölçüde tatmin olup olmadığını ifade etmektedir. Dolayısıyla hizmet kalitesi kavramı, alıcının gereksinimi ve beklentileri, bu gereksinim ve beklentiler doğrultusunda hizmette bulunması 
gereken özellikler ve hizmetin bu özellikleri bulundurma derecesi olarak ifade edilebilir (Özveren, 2010:32).

Müşterinin hizmeti tükettikten sonraki algılama hissi, hizmet kalitesini ortaya koymaktadır. Hizmet kalite algılaması, müşterinin kullandığ 1 hizmet ile ilgili düşünceleridir. Bunun sonucu olarak müşterinin hizmet kalitesi beklentisi, hizmet kalitesini algılamasını etkilemektedir (Özveren, 2010:32). Oliver ve Rust (1994)'e göre, müşterilerde hizmet kalitesi algısının oluşması için, hizmetin satın alınması gerekmemekle birlikte, tatmin, ürün satın alınıp kullanıldıktan sonra meydana gelmektedir (akt. Koç, 2007:48).

Parasuraman, Zeithaml ve Berry (1985), hizmet kalitesi kavramına geniş bir perspektiften bakmak amacıyla kavramsal bir hizmet kalitesi modeli geliştirmişlerdir. Onlara göre hizmet kalitesi yaklaşımı, müşterilerin hizmetten beklentileri ile hizmete yönelik algıların karşılaştırılması esasına dayanmaktadır. Beklenen hizmet algılanan hizmetten büyük olursa, algılanan kalitenin tatmin düzeyi düşük olacaktır. Beklenen hizmet algılanan hizmete eşitse, algılanan kalite ve dolayısıyla hizmet tatmin edici boyuttadır. Müşteri tarafindan algılanan kalitenin ideal kalitede olması için, beklenen hizmetin algılanan hizmetten daha düşük düzeyde olmas1 gerekmektedir (Parasuraman, Zeithaml ve Berry, 1985:41-42; Subaş1, 2010:24).

Sasser, Olsen ve Wyckoff(1978), Gronroos(1982), Lehtinen ve Lehtinen(1982) ile Liwes ve Booms(1983), hizmet kalitesi kavramında üç noktayı vurgulamışlardır (akt. Çelik, 2012:18):

1. Hizmet kalitesinin değerlendirilmesi, ürün kalitesinin değerlendirilmesinden çok daha zordur.

2. Müşterilerin hizmete ulaşmadan önceki beklentileri ile gerçekleşen deneyimlerini karşılaştırmaları sonucunda, müşterilerin hizmet kalitesi algılaması ortaya çıkar.

3. Kalitenin değerlendirilmesi sadece hizmet çıktısı değildir. Hizmet teslim sürecinde de önemlidir.

Hizmet kavramının kazandırdığı faydanın nicel ölçütlerle değerlendirilmesi zor olduğundan, hizmet kalitesinin ölçülmesi normal ürün kalitesi ölçümüne nazaran daha zordur (Eleren ve Kılıç, 2007:242). Hizmet sektörünün ve buna bağlı olarak hizmet pazarlaması ve hizmet kalitesi kavramlarının önem kazanmaya başladığ 1 1970'li yıllardan bu yana, hizmet kalitesi ve hizmet kalitesinin ölçümü üzerine modeller geliştirilmiş ve ölçekler oluşturulmuştur (Alakavuk, 2007:330).

SERVQUAL Modeli, Parasuraman, Zeithaml ve Berry (1985) tarafından geliştirilmiş, literatürde geçerliliğini kanıtlamış ve yaygın olarak kullanılan bir hizmet kalitesi ölçüm modelidir. Model, onaylamama paradigmasına dayanmaktadır. Bu paradigmaya göre, müşteri beklentisi ile müşterinin elde ettiği hizmetin birbiriyle tam olarak örtüşmesi, beklenti ile algılanan performansın birbirini onaylaması anlamına gelmektedir. Aynı mantıkla, beklenti elde edilen hizmetten daha fazla ise negatif onaylamama, elde edilen hizmet beklentinin üzerinde ise pozitif onaylamama söz konusudur. Başka bir ifadeyle alınan hizmet beklentileri karşılıyor ise hizmetin kaliteli olduğu sonucuna varılmaktadır. Alınan hizmet beklentilerin altında ise hizmet kaliteli olmayıp memnuniyetsizlik oluşmaktadır (Parasuraman, Zeithaml ve Berry (1985); Okumuş ve Duygun, 2008:20). Model, Şekil 1'de görülmektedir: 
Şekil 1: Alg1lanan Hizmet Kalitesini Belirleyen Faktörler

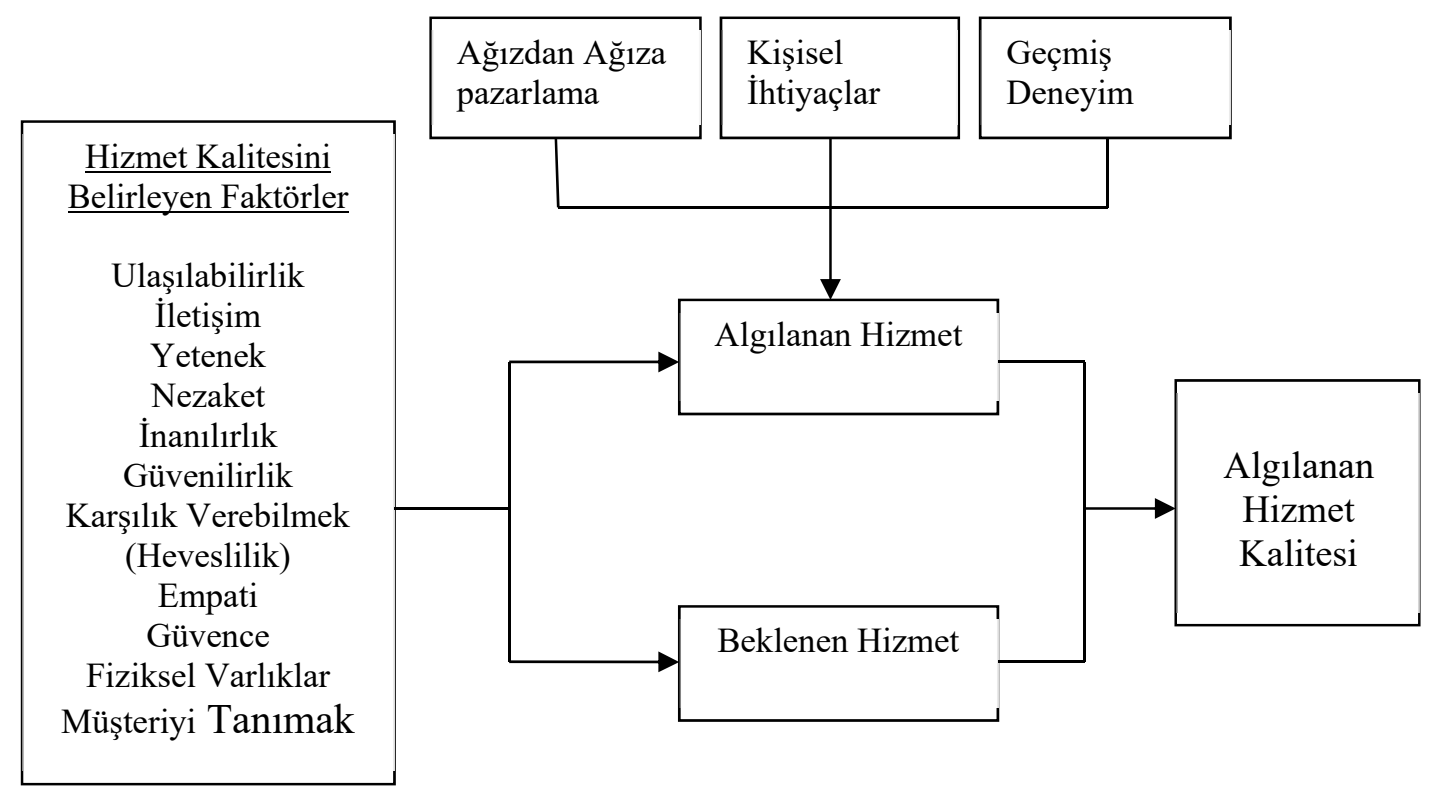

Kaynak: Parasuraman, Zeithaml ve Berry, 1985:48.

Parasuraman, Zeithaml ve Berry (1985), hazırladıkları ölçekte öncelikle hizmet kalitesini tanımlamak, hizmet kalitesini etkileyen unsurları belirlemek ve buna dayalı hizmet kalitesinin ölçülebilir olmasını sağlamak amacıyla genel bir model geliştirmeye çalışmışlardır. SERVQUAL Modeli geliştirilirken, üç ana konu üzerinde cevap aramaya yoğunlaşılmıştır. Bunlar, "Hizmet kalitesi nedir?", "Neler hizmet kalitesi problemlerine yol açar?" ve "Ne çeşit organizasyonlar hizmet kalitesinin sorununu çözer ve hizmetleri geliştirebilir?" konularıdır (Parasuraman, Zeithaml ve Berry, 1985:47-48).

SERVQUAL Modeline göre müşterilerin, beklentileri ile hizmet sunan işletme performansından algıladıkları şey arasındaki fark, algılanan hizmet kalitesidir. Dolayısıyla model iki ana kısımdan oluşmaktadır. Birinci kısım beklentilerdir. Bu kısımda müşterinin hizmetle ilgili genel beklentilerini ölçmeye yardımcı olacak beş hizmet boyutuna ilişkin ve müşteri değer yargılarına göre belirlenen yirmi iki önerme yer almaktadır (Değermen, 2006:38). Modelin ikinci kısmını ise algılamalar oluşturmaktadır. Bu kısımda da hizmet sunan işletme hakkındaki müşteri değerlendirmelerini ölçen beş hizmet boyutuna ilişkin yirmi iki önerme bulunmaktadır. Bu nedenle ölçüm gerçekte kırk dört önerme üzerinden yapılmaktadır (Çelik, 2012:24).

Ölçümde 7'li Likert ölçeği (1. Hiç Katılmıyorum-7. Tamamen Katılıyorum) kullanılmaktadır. Modelde müşteri algılarını ölçmeden önce, hizmet kalitesi boyutları ile ilgili beş ifadeye boyutların ismi belirtilmeden yer verilmekte ve müşterilerden boyutlara verdikleri önem derecelerine göre 100 puanı bu boyutlar arasında paylaştırmaları istenmektedir. SERVQUAL ölçeği, alg1 ve beklenti farkına dayalı olarak beş boyutta kalite ölçümünü gerçekleştirerek müşterilerin algıladığı genel hizmet kalitesini ortaya çıkarmaktadır. Ayrıca işletme yöneticilerinin kaliteyi geliştirmede temel alacağı önemli boyutların belirlenmesini sağlamaktadır (Çelik, 2012:24).

Aynı zamanlardaki müşteri beklenti ve algılamalarının karşılaştırılması, firmanın SERVQUAL skorlarının rakip firmaların SERVQUAL skorları ile karşılaştırılması, kalite 
algısı farklı olan müşteri gruplarının incelenmesi ve iç müşterilerin kalite algılarının değerlendirilmesi, modelin diğer kullanım amaçları arasında yer almaktadır (Çelik, 2012:24).

SERVQUAL ölçeğinde yirmi iki maddeyi içeren ifadelerden 1-4 arası fiziksel unsurlara ait boyutları, 5-9 arası güvenlik boyutunu, 10-13 arası yeterlilik boyutunu, 14-17 arası güvence boyutunu ve 18-22 arası, empati boyutunu içermektedir (Gürbüz, 2005:102).

Hizmet kalitesi boyutlarını içeren ifadeler Tablo 1'de yer almaktadır:

Tablo 1: Hizmet Kalitesi Boyutlarını İçeren İfadeler

\begin{tabular}{|c|c|}
\hline $\begin{array}{c}\text { Fiziksel } \\
\text { Unsurlar }\end{array}$ & $\begin{array}{l}\text { 1. Mükemmel işletmeler modern görünüşlü bir donanıma sahiptirler. } \\
\text { 2. Mükemmel işletmelerin binaları görsel olarak çekicidir. } \\
\text { 3. Mükemmel işletmelerin çalışanları düzgün görünüşlüdür. } \\
\text { 4. Mükemmel işletmelerde hizmete eşlik eden malzemeler görsel olarak çekicidir. }\end{array}$ \\
\hline Güvenilirlik & $\begin{array}{l}\text { 5. Mükemmel işletmeler verdikleri sözü zamanında yerine getirirler. } \\
\text { 6. Mükemmel işletmeler müşterilerinin bir problemi olduğunda, çözmek için samimi bir ilgi } \\
\text { gösterirler. } \\
\text { 7. Mükemmel işletmeler hizmeti ilk seferinde doğru olarak verirler. } \\
\text { 8. Mükemmel işletmeler hizmetleri söz verdikleri zaman içinde yerine getirirler. } \\
\text { 9. Mükemmel işletmeler hatasız kayıt tutmaya özen gösterirler. }\end{array}$ \\
\hline Yeterlilik & $\begin{array}{l}\text { 10. Mükemmel işletmelerin çalışanları hizmetin ne zaman verileceğini müşterilere söylerler. } \\
\text { 11. Mükemmel işletmelerin çalışanları hizmeti mümkün olan en kısa sürede gerçekleştirirler. } \\
\text { 12. Mükemmel işletmelerin çalışanları müşterilere her zaman yardımcı olmaya çalışırlar. } \\
\text { 13. Mükemmel işletmelerin çalışanları hiçbir zaman müşterinin isteklerine cevap } \\
\text { veremeyecek kadar meşgul değildirler. }\end{array}$ \\
\hline Güven & $\begin{array}{l}\text { 14. Mükemmel işletmelerin çalışanları müşterilerde güven duygusu uyandırır. } \\
\text { 15. Mükemmel işletmelerde müşteriler kendilerini güvende hissederler. } \\
\text { 16. Mükemmel işletmelerin çalışanları müşterilere karşı daima saygılıdırlar. } \\
\text { 17. Mükemmel işletmelerin çalışanları müşterilerin sorularına cevap verecek bilgiye } \\
\text { sahiptirler. }\end{array}$ \\
\hline Empati & $\begin{array}{l}\text { 18. Mükemmel işletmeler her müşteriye özel ilgi gösterirler. } \\
\text { 19. Mükemmel işletmelerin çalışma saatleri bütün müşterilere uygun olacak şekildedir. } \\
\text { 20. Mükemmel işletmeler her müşteriye kişisel olarak ilgilenecek çalışanlara sahiptirler. } \\
\text { 21. Mükemmel işletmeler müşterilerin çıarlarını her şeyden üstün tutarlar. } \\
\text { 22. Mükemmel işletmelerin çalışanları müşterilerin özel isteklerini anlarlar. }\end{array}$ \\
\hline
\end{tabular}

Kaynak: Koçoğlu, M, 2009:41.

\section{Müşteri Memnuniyeti Kavramı Literatür İncelemesi}

Müşteri memnuniyeti, müşterilere değer yaratma eğiliminde olan, beklentilerini tatmin eden ve yöneten, ihtiyaçlarını karşılama yeteneği ve sorumluluğunu gösteren bir iş felsefesidir. Dolayısıyla hizmet kalitesi ve müşteri memnuniyeti işletmelerin başarısı için kritik faktörlerdir. İşletmelerin hayatta kalabilmelerinin en önemli anahtarı, memnun müşteri ile sonuçlanan yüksek kaliteli hizmet sunabilmektir (Dominici ve Guzzo, 2010:3).

Müşteri memnuniyeti en kısa ve öz tanımıyla, müşteri beklentileri ile mevcut durum arasındaki farktır. Müşteri memnuniyeti, müşterinin ürün ya da hizmetten beklentileri ile karşılaştığı durum arasındaki farkın bir sonucu olarak ortaya çıkar (Güllülü vd., 2008:24). Üretim, satış ve satış sonrası uygulamaların müşteri beklentilerine uygun olarak düzenlenmesi ve müşteri beklentilerini karşılaması göz önüne alındığında müşteri memnuniyeti, müşterinin üründen beklentileriyle ürünün yapması gereken iş ve bu işi yapabilme başarısının uyuşması, satış sonrası hizmetlerin müşteri beklentilerini karşılamasıdır (Çakır ve Eğinli, 2010:80). Özveren (2010)'e göre müşteri memnuniyeti, ürün ya da hizmetin tüketici beklentilerini ne düzeyde karşılayıp karşılayamadığıdır. Buna göre ürün ya da hizmet, kişinin beklentilerini 
istediği düzeyde karşılarsa, kişinin memnuniyetinden söz edilebilir. Fakat kişinin beklentilerini istediği düzeyde karşılayamamışsa, memnuniyetsizlik, tatminsizlik oluşur (Ertürk ve Kıyak, 2011).

Ancak şu ana kadar müşteri memnuniyeti kavramı, müşterinin ürün ve hizmet performansından beklentileri olarak ele alınmıştır. Oysa performans ve kalitenin yanı sıra müşteriyle olan ilişki, müşteriye karşı tutum ve davranışlar da müşteri memnuniyetinde ve tatmininde göz ardı edilemez. Müşteri memnuniyeti, müşterilerin aldıkları hizmetten bekledikleri faydalara, müşterinin katlanmaktan kurtulduğu külfetlere, hizmetten beklediği performansa, hizmetin sunuluşunun sosyo-kültürel değerlerine, kendi aile ve kültürüne, sosyal sınıf ve statüsüne, zevk ve alışkanlıklarına ve yaşam tarzına uygunluğuna bağlı bir fonksiyon haline gelmiştir (Çınar, 2007:21).

Müşteri memnuniyeti, tüketim sırasında hissedilen duygularla tüketim sonrasında hissedilen duyguların değerlendirilmesinin bir sonucudur. Satın alma sonrası müşteride oluşan duygusal tepkinin birbirinden bağımsız olan pozitif veya negatif etkileri memnuniyet değerlendirmesini etkiler (akt. Yalçın, 2012:43).

Müşteri memnuniyeti, müşterilerin bir ürün veya hizmeti satın almayı düşündükleri, satın aldıkları, kullanmaya başladıkları ve kullandıkları bir süreçte, bu ürün ya da hizmetle ilgili geliştirdikleri tutum ve davranışlardır (Çakır ve Eğinli, 2010:81).

Başka bir tanıma göre müşteri memnuniyeti, müşterinin ürün ya da hizmet tüketimi süresince ihtiyaç, istek ve beklentilerinin bir sonraki ürün/hizmet talebini ve ürün/hizmete bağlılığını etkilediği karşılanma derecesidir (akt. Balc1, 2010: 58).

Oliver (1980)'e göre müşteri memnuniyeti, onun tatmin olma tepkisidir ve bir mal veya hizmetin tamamından ya da bir özelliğinden tüketimle ilgili keyif verici tatminkârlık yargısıdır (Oliver, 1980:460). Anderson (1994)'e göre müşteri memnuniyeti, tüketicinin üründen beklediği fayda ile elde ettiği fayda arasındaki olumlu ilişkidir (Anderson, 1994:19). LeBlanck (1992) ve Bae(2012)'ye göre ise, müşterinin ürün ya da hizmeti satın almadan önceki algıladığ1 performans ile satın aldıktan sonraki algıladığı performans arasındaki farklılıktan doğan tutarsızlığın fonksiyonudur. Buna göre müşteri memnuniyeti, doğrudan beklentilerden ve algılanan performanstan; dolaylı olarak ise, beklenti-algılama tutarsızlığından etkilenir (Leblanck, 1992: 10; Bae, 2012:8).

Müşteri memnuniyeti, müşterinin satış öncesi ve satış sonrası bütün ihtiyaçlarını karşılamakla sağlanır. Müşteri memnuniyeti işletmeler açısından müşterilerin ihtiyaçlarının belirlenmesi ve onlara ürün ve hizmetlerin nasıl sunulması gerektiği hususunda birincil kaynaktır. Müşteriler memnuniyet kararlarını yalnız ürün ve hizmete bağlı olarak değil, bu ürün ve hizmeti kullanmalarından sonra edindikleri deneyime bağlı olarak da verirler. Memnun müşteriler, doğru ürün kombinasyonu, pazarlama ve satış desteği, fiyat, itibar, ürün dizaynı ve kullanıma uygunluk konularında iyi bir deneyim yaşadıklarını hisseden kişilerdir (Acuner, 2001:17-18).

Müşteri memnuniyeti, fiziksel ürünler için ürünü satın aldıktan sonra ürünün kalite ve performans gibi kriterlere göre değerlendirilmesiyle; hizmetlerde ise, müşterinin hizmeti aldığ1 sırada beklentilerinin karşılanıp karşılanmamasına göre ortaya çıkar. Yani müşterinin memnuniyeti ya da memnuniyetsizliği, onun beklentileri ile algılamalarını kıyaslamasının bir sonucudur. Müşterinin satın aldığı mal ya da hizmetin sağladığı faydalar ile müssteri beklentilerinin uyuştuğu noktada memnuniyet meydana gelir (Özgüven, 2008:657).

Müşteriyi memnun etmek, onu tatmin etmek, sürekli kılmak, onun ihtiyaç ve beklentilerini istediği ölçüde karşılamak, işletmelerin çok daha yoğun çaba harcamasını 
gerektiren, strateji ve politikalarını müşterileri doğrultusunda yönetmeyi zorunlu kılan faaliyetler zinciri (Bilir, 2010:49); işletme performansının ve pazarlama faaliyetlerinin başarısını etkileyen bir faktördür (Balc1, 2010: 58). Bu açıdan işletmeler rekabet üstünlügü sağlamak için, stratejilerinin temeline müşterileri yerleştirmek, onların taleplerini önceden tahmin edip, en uygun maliyetle karş1lamak durumundadırlar (Naktiyok ve Küçük, 2003:225).

Müşteri memnuniyeti, örgütsel yapıyla karşılıklı etkileşim içerisinde olmasına rağmen, birçok işletme müşterilerinin beklentilerinden habersizdir. Oysa müşteri memnuniyeti, işletme devamlılı̆̆ için gerekli teknik konulardan çok daha önemlidir (Can, 2010:18).

Müşterilerin istek ve ihtiyaçlarını karşılamanın ve onları memnun etmenin en iyi yolu müşteri memnuniyetinin ölçülerek takip edilmesidir (Yalçın, 2012:57). Müşteri memnuniyetini ölçmekteki başlıca amaç, müşterilerin nelerin değişmesini istediklerine ilişkin bilgi toplamak ya da bir işletmenin bu istekleri ne kadar anlayıp müşterilerine nasıl bir hizmet sunmakta olduğunu değerlendirmek ve sadık müşterilerin sayısını ve mevcut müşterilerin bağlılığını artırmaktır (Coşar, 2006:38). Müşteri memnuniyetinin ölçülmesi için müşterinin kim olduğunun ve memnuniyetin anlamının bilinmesi gerekir (Rasila, 2009:39)

Müşteri memnuniyetinin ölçülmesinde dikkat edilmesi gereken unsurlar vardır. Bunlar içinde işletmeler tarafından sunulan ürün ve hizmetlerin müşteri tarafindan nasıl algılandığı, hangi ölçütler içinde değerlendirildiği, firma tarafından kalite olarak nitelendirilen unsurlardan hangilerinin müşteriler tarafından fark edildiği ve önemsendiği ya da müşterinin kalite boyutu olarak beklenti içinde olduğu ancak firma tarafindan göz ardı edilen unsurların neler olduğudur (Yalçın, 2012:57). Bir diğer unsur, müşteri memnuniyet araştırmalarıdır. Müşteri memnuniyet araştırmaları firmaların sağlıklı şekilde faaliyette bulunup bulunmadığının önemli bir göstergesidir ama sadece bu sonuçlara dayanarak hareket edilmesi doğru olmayabilir (Tak, 1998:578). Müşteri memnuniyeti ölçümü yapılırken algısal verilere ve müşterilerin söylediklerine fazla güvenmemek gerekir. Her sektör için sektör dinamikleri ve memnuniyet etkenleri sürekli ve hızlı bir şekilde değişirken algılarla ya da ön yargılarla yapılacak ölçümlerin sağlıklı olma ihtimali düşüktür (Törtop, 2008). Çünkü müşteri memnuniyet araştırmaları, müşterilerin firma stratejisine ve yenilikçi ürün veya hizmet geliştirme süreçlerine yön vermesi konusunda gerekli verileri sağlayamamaktadır (Tak, 1998:578).

İşletmelerin müşteri memnuniyetinde başarılı olabilmeleri için memnuniyeti nasıl ölçeceklerini, nasıl izleyeceklerini, verilerin nasıl toplanıp analiz edileceğini ve stratejik bir silah olarak nasıl kullanacaklarını bilmeleri gerekir (akt. Coşar, 2006:38).

Müşteri memnuniyet ölçümleri genel olarak işlem bazlı memnuniyet ve kümülatif bazlı memnuniyet olmak üzere iki farklı değerlendirme yöntemi üzerine şekillenmiştir. İşlem bazlı memnuniyet ölçüm modelleri, gerçekleşen bir işlem için müşterinin memnuniyet seviyesini ölçüp değerlendirme yapmak şeklindedir ve son zamanlarda müşterinin ürün ve hizmetten algıladığı kalite, memnuniyet derecesi ve duyguların tatmin üzerindeki rolü arasındaki ilişkileri de ölçmek üzere uygulanabilmektedir. Kümülatif ölçüm modelleri ise, son yıllarda daha çok ekonomik göstergeler üzerinde modellenmiştir. $\mathrm{Bu}$ yaklaşım, müşteri memnuniyetini, müşterinin ürün veya hizmet sunucusuyla olan genel tecrübelerini tanımlar. Bu modelin en büyük avantajı genel müşteri bilgilerini kullanarak mevcut ve gelecekteki müşteri davranışları hakkında tahmin imkânı sunmasıdır (Türkyılmaz ve Coşkun, 2003:2).

Müşteri memnuniyetini ölçme ve değerlendirmeye yönelik uygulamalar artık kalite standartları arasında da yer almaktadır. ISO 9001 kalite sistem standartlarının 2000 yılı versiyonunda müşteri memnuniyetinin periyodik olarak ölçülmesi, izlenmesi, bu konudaki bilgilerin elde edilmesi ve kullanımına ilişkin prosedürlerin oluşturulması zorunluluk olarak 
standartlara dâhil edilmiştir. $\mathrm{Bu}$ standartlara sahip olmak isteyen firmalar, müşteri memnuniyetini düzenli olarak ölçmek, izlemek ve bunu nasıl yaptıklarını belgelemek durumundadırlar (Coşar, 2006:41).

\section{Yöntem}

Çalışmanın amacı, mobil reklamcılıkta bireysel müşteri hizmet kalitesi ile müşteri memnuniyeti arasındaki ilişkiyi değerlendirmektir. Çalışmanın ana kütlesini Facebook, Twitter ve Linkedin kullanıcıları oluşturmaktadır. TÜİK 2014 yılı verilerine göre Türkiye'de sosyal medya kullanıcı sayısı sırasıyla Facebook'ta otuz altı milyon (48 milyon), Twitter'da on bir milyon beş yüz bin ve Linkedin'de dört milyon üç yüz bindir. Bu üç sosyal medya kullanıcılarının kadın/erkek oranı ise sirasıyla Facebook'ta \%36/64, Twitter'da \%62/38 ve Linkedin'de \%54/46'dır. Sosyal medya kadın/erkek kullanıcı oranları sirasıyla Facebook'ta \%58/42, Twitter'da \%62/38 ve Linkedin'de \%54/46'dır. Sosyal medya kadın kullanıcı oranının ortalaması \%58 $((58+62+46) / 3)$; erkek kullanıcı oranının ortalaması ise \%42 olarak hesaplanmıştır. Aşağıda, \%95 güven aralığında, 0,05 hata yapma düzeyinde, oranlar yöntemiyle araştırmanın örnek hacmi hesaplanmıştır:

$$
\begin{gathered}
\frac{\mathrm{N} \times(\mathrm{p} \times \mathrm{q}) \times \mathrm{Z}^{2}}{(\mathrm{~N}-1) \times \mathrm{E}^{2}+(\mathrm{p} \times \mathrm{q}) \times Z^{2}} \\
\frac{51.800 .000 \times(0.58 \times 0.42) \times(1.65)^{2}}{51.799 .999 \times(0.05)^{2}+(0.58 \times 0.42) \times(1.65)^{2}} \\
\frac{34.322 .265,6}{129.499 .99+0.66} \\
\mathrm{n}=265
\end{gathered}
$$

Çalışmada hatalı anketlerin de olabileceği varsayılarak 500 kişiye anket uygulanmış, geçerli olan 436 anket analiz edilmiştir.

Mobil reklamcılıkta müşteri memnuniyetini belirleyen hizmet kalitesi ve algılanan müşteri memnuniyeti boyutlarına ilişkin kavramsal model aşağıdaki gibi geliştirilmiştir: 
Şekil 2: Mobil Reklamcılıkta Algılanan Hizmet Kalitesi Değişkenleri ve Algılanan Müşteri Memnuniyeti Değişkenleri İle Müşteri Memnuniyeti Arasındaki İlişkiye Dair Kavramsal Model

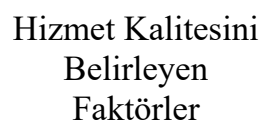

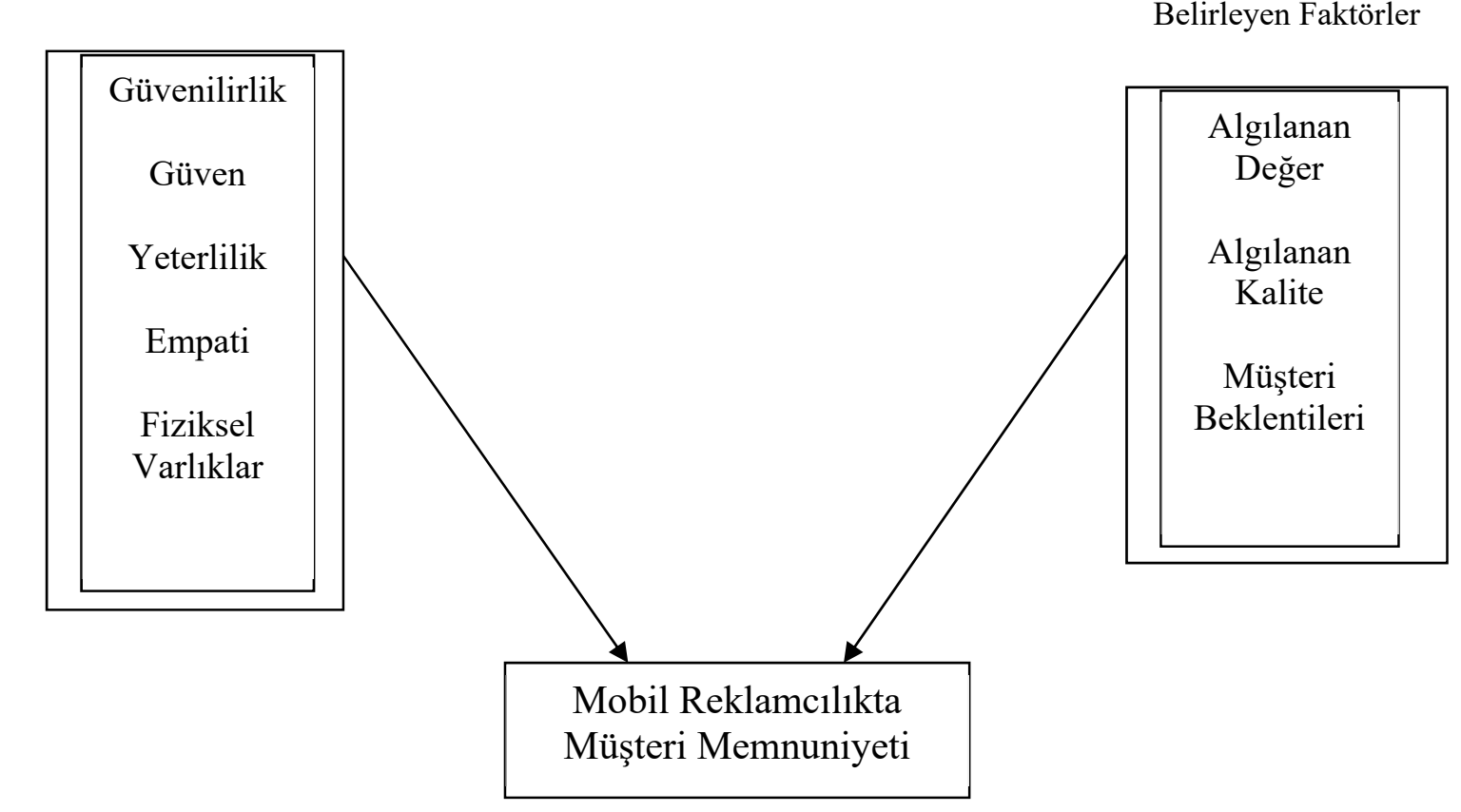

Algilanan Müşteri

Memnuniyetini

Belirleyen Faktörler

Şekil 2'deki araştırmaya dair kavramsal model incelendiğinde Hizmet Kalitesinin Güvenilirlik, Güven, Yeterlilik, Empati ve Fiziksel Varlıklar olmak üzere beş değişkenden oluştuğu görülmektedir. $\mathrm{Bu}$ değişkenlerdeki iyileşmeler hizmet kalitesi düzeyini doğrudan etkileyebilecektir. Modelde yer alan Algılanan Müşteri Memnuniyeti Düzeyi ise, Algılanan Değer, Algılanan Kalite ve Müşteri Beklentileri olmak üzere üç değişkenden oluşmaktadır. Bu değişkenlerdeki iyileşmeler de algılanan müşteri memnuniyeti düzeyini olumlu yönde etkileyebilecektir. Modele göre mobil reklamc1lıkta müşteri memnuniyeti ile hizmet kalitesi ve algılanan müşteri memnuniyeti arasında ilişki bulunmaktadır. Bu anlamda mobil reklamcılıkta işletmelerin müşterilerine sunmuş oldukları hizmet kalitesi düzeyi ile müşteri memnuniyeti arasında anlamlı bir ilişki olduğu ifade edilebilir. Modelde ayrıca algılanan müşteri memnuniyeti düzeyi ile müşteri memnuniyeti arasında da bir ilişki olduğu görülmektedir. Müşteri memnuniyetini oluşturan değişkenlerin algılanma düzeyi ile hizmet kalitesi boyutlarının algılanma düzeyinin, mobil reklamcılıkta müşteri memnuniyetini etkileyebileceği varsayılmaktadır. Çalışmanın amacı ve varsayımı kapsamında aşağıdaki hipotezler geliştirilebilir. 
H1: Mobil reklamcılıkta müşteri hizmetleri kalitesi düzeyi ile mobil reklamcılıkta müşteri memnuniyeti arasında anlamlı bir ilişki vardır.

H1a: Mobil reklamcılıkta müşteri hizmetleri kalitesinin güvenilirlik düzeyi ile mobil reklamcılıkta müssteri memnuniyeti arasında anlamlı bir ilişki vardır.

H1b: Mobil reklamcılıkta müşteri hizmetleri kalitesinin güven düzeyi ile mobil reklamcllıta müşteri memnuniyeti arasında anlamlı bir ilişki vardır.

H1c: Mobil reklamcllıkta müşteri hizmetleri kalitesinin yeterlilik düzeyi ile mobil reklamcllıkta müşteri memnuniyeti arasında anlamlı bir ilişki vardır.

H1d: Mobil reklamcllıta müşteri hizmetleri kalitesinin empati düzeyi ile mobil reklamcılıkta müşteri memnuniyeti arasında anlamlı bir ilişki vardır.

H1e: Mobil reklamcllıkta müşteri hizmetleri kalitesinin fiziksel varlıklar düzeyi ile mobil reklamcılıkta müşteri memnuniyeti arasında anlamlı bir ilişki vardır.

H2: Algllanan müşteri memnuniyeti düzeyi ile mobil reklamcılıkta müşteri memnuniyeti arasında anlamlı bir ilişki vardır.

H2a: Algılanan müşteri memnuniyetinin algılanan değer düzeyi ile mobil reklamcılıkta müşteri memnuniyeti arasında anlamlı bir ilişki vardır.

H2b: Algllanan müşteri memnuniyetinin algllanan kalite düzeyi ile müşteri memnuniyeti arasında anlamlı bir ilişki vardır.

H2c: Algllanan müşteri memnuniyetinin müşteri beklentileri düzeyi ile müşteri memnuniyeti arasında anlamlı bir ilişki vardır.

Çalışma verilerinin toplanmasında anket tekniğinden yararlanılmıştır. Anket formunun birinci bölümü, demografik özellikleri belirlemeye yönelik çoktan seçmeli sorulardan oluşmaktadır. Demografik özelliklere ilişkin bölümde; çalışanların cinsiyetini, yaşını, eğitimini, mesleğini ve gelirini belirlemeye yönelik beş adet çoktan seçmeli soru bulunmaktadır. İkinci bölümde, hizmet kalitesini etkileyen boyutları ölçmek amacıyla Parasuraman, Berry ve Zeithaml(1985) tarafindan geliştirilen SERVQUAL model ölçeği kullanılmıştır. Bu bölümde, hizmet kalitesi düzeyini belirleyen "Fiziksel Özellikler", "Güvenilirlik", "Güven", "Yeterlilik" ve "Empati" boyutlarına ilişkin ölçek ifadeleri yer almaktadır. Üçüncü bölümde ise müşteri memnuniyetini etkileyen boyutları ölçmek amacıyla Richard Oliver (1980) tarafından geliştirilen müşteri memnuniyeti modeli kullanılmıştır ve müşteri memnuniyeti düzeyini belirleyen "Algılanan Değer", "Algılanan Kalite" ve "Müşteri Beklentileri” boyutlarına ilişkin ölçek ifadelerine yer verilmiştir. Ankette 7’li Likert tipi ölçekten yararlanılmıştır.

Çalışmada anket tekniğiyle elde edilen veriler incelenmiş ve araştırmaya katılanların eksiksiz olarak cevaplandırdığ 1 anketler değerlendirmeye alınmıştır. Verilerin analizinde SPSS 17.0 istatistik paket programından yararlanılmıştır. Ölçeklerin güvenilirliğini belirlemek amaciyla Cronbach $\alpha$ değeri hesaplanmış ve \%89,9 olarak bulunmuştur. Mobil reklamcılıkta hizmet kalitesi unsurları ve algılanan müşteri memnuniyeti ile mobil reklamcılıkta müşteri memnuniyeti arasındaki ilişkileri test etmek amacıyla çoklu doğrusal regresyon analizi kullanılmıştır. Katılımcıların demografik özellikleri ve belirlenen ölçeklere katılım düzeylerini belirlemek amacıyla yüzde ve frekansları içeren tanımlayıcı istatistiklerden yararlanılmıştır. 


\section{Verilerin Analizi ve Bulgular}

\subsection{Katılımcıların Demografik Özelliklerine İlişkin Tanımlayıcı İstatistikler}

Katılımcıların cinsiyet, yaş, eğitim, meslek ve gelir durumlarını belirlemeye yönelik sorulara ilişkin tanımlayıcı bulgular Tablo 2'de yer almaktadır.

Tablo 2: Katılımcıların Demografik Özelliklerine İlişkin Bulgular

\begin{tabular}{|c|c|c|c|c|c|}
\hline CINSIYYET & $\mathbf{N}$ & $\%$ & EĞİTİM & $\mathbf{n}$ & $\%$ \\
\hline Kadın & 191 & 43.8 & İlkokul & 1 & 0.2 \\
\hline Erkek & 245 & 56.2 & Ortaokul & 5 & 1.1 \\
\hline \multirow[t]{2}{*}{ TOPLAM } & 436 & 100.0 & Lise & 44 & 10.1 \\
\hline & & & Yüksekokul & 103 & 23.6 \\
\hline YAŞ & $\mathbf{N}$ & $\%$ & Lisans & 175 & 40.1 \\
\hline $18-22$ & 100 & 22.9 & Yüksek lisans & 89 & 20.4 \\
\hline $23-27$ & 187 & 42.9 & Doktora & 19 & 4.4 \\
\hline $28-32$ & 85 & 19.5 & TOPLAM & 436 & 100.0 \\
\hline $33-37$ & 19 & 4.4 & & & \\
\hline $38-42$ & 13 & 3.0 & MESLEK & $\mathbf{n}$ & $\%$ \\
\hline 43 ve üzeri & 32 & 7.3 & Çalışmiyorum & 123 & 28.2 \\
\hline \multirow[t]{2}{*}{ TOPLAM } & 436 & 100.0 & Memur & 57 & 13.1 \\
\hline & & & İşçi & 15 & 3.4 \\
\hline GELİR & $\mathbf{N}$ & $\%$ & Serbest Meslek & 39 & 8.9 \\
\hline Gelirim yok & 163 & 37.4 & Akademisyen & 58 & 13.3 \\
\hline $600.00-1499.99 \mathrm{TL}$ & 72 & 16.5 & Öğretmen & 18 & 4.1 \\
\hline $1.500 .00-1899.99 \mathrm{TL}$ & 31 & 7.1 & Emekli & 3 & 0.7 \\
\hline $1.900 .00-2.299 .99 \mathrm{TL}$ & 54 & 12.4 & Diğer & 123 & 28.2 \\
\hline $2.300 .00-2.699 .99 \mathrm{TL}$ & 60 & 13.8 & TOPLAM & 436 & 100.0 \\
\hline 2.700.00 TL ve üzeri & 56 & 12.8 & & & \\
\hline TOPLAM & 436 & 100.0 & & & \\
\hline
\end{tabular}

Ankete katılan katılımcıların \%43,8'i kadın, \%56,2'si erkektir. Katılımcıların \%65,8'i genç, \%23,9'u orta yaş, \%10,3'ü orta yaş üstüdür. \%98,4'ü en az lise mezunudur. Katılımcıların \%71,7'si çalışan kesim içerisinde yer alıp, \%46'sı 1.500 TL ve üzeri gelire sahiptir.

\subsection{Katılımcıların Hizmet Kalitesi Değişkenlerini Algılama Düzeylerine İliş̧kin Tanımlayıcı İstatistikler}

Hizmet kalitesi, Güvenilirlik, Güven, Yeterlilik, Empati ve Fiziksel Varlıklar olmak üzere beş boyuttan oluşmaktadır. Bu beş boyutta meydana gelen iyileşmeler, hizmet kalitesi düzeyini doğrudan etkilemektedir. Aşağıdaki tabloda hizmet kalitesi değişkenlerinin algılanma düzeylerine ilişkin bulgular yer almaktadır. 
Tablo 3: Hizmet Kalitesi Değişkenlerinin Algılanma Düzeyine İlişkin Bulgular

\begin{tabular}{|c|c|c|c|c|c|c|c|c|}
\hline FİZIKSEL VARLIKLAR & $\begin{array}{c}1 \\
\mathrm{n} / \%\end{array}$ & $\begin{array}{c}2 \\
\mathrm{n} / \%\end{array}$ & $\begin{array}{c}3 \\
\mathrm{n} / \%\end{array}$ & $\begin{array}{c}4 \\
\mathrm{n} / \%\end{array}$ & $\begin{array}{c}5 \\
\mathrm{n} / \%\end{array}$ & $\begin{array}{c}6 \\
\mathrm{n} / \%\end{array}$ & $\begin{array}{c}7 \\
\mathrm{n} / \%\end{array}$ & $\begin{array}{c}\text { Toplam } \\
\text { n/\% }\end{array}$ \\
\hline $\begin{array}{l}\text { Reklamı yapan personel güzel ve } \\
\text { düzgün bir ses tonuna sahiptir. }\end{array}$ & $9 / 2.1$ & $24 / 5.5$ & $16 / 3.7$ & $29 / 6.7$ & $81 / 18.6$ & $\begin{array}{l}207 / 47 \\
5\end{array}$ & $70 / 16.1$ & $436 / 100.0$ \\
\hline $\begin{array}{l}\text { Reklamı yapan personelin } \\
\text { konuşması naziktir. }\end{array}$ & $6 / 1.4$ & $14 / 3.2$ & $12 / 2.8$ & $19 / 4.4$ & $80 / 18.3$ & $\begin{array}{l}222 / 50 \\
9\end{array}$ & $83 / 19.0$ & $436 / 100.0$ \\
\hline $\begin{array}{l}\text { Reklam hizmeti kesintisiz bir } \\
\text { iletişim ortamında sunulur. }\end{array}$ & $13 / 3.0$ & $39 / 8.9$ & $16 / 3.7$ & $57 / 13.1$ & $82 / 18.8$ & $\begin{array}{c}175 / 40 \\
1\end{array}$ & $54 / 12.4$ & $436 / 100.0$ \\
\hline $\begin{array}{l}\text { Reklam amaciyla yapılan sesli } \\
\text { çağrılar genellikle bana uygun } \\
\text { zaman dilimlerinde yapılır. }\end{array}$ & $147 / 33.7$ & $125 / 28.7$ & $36 / 8.3$ & $39 / 8.9$ & $53 / 12.2$ & $23 / 5.3$ & $13 / 3.0$ & $436 / 100.0$ \\
\hline $\begin{array}{l}\text { Reklamı yapılan kampanyalar } \\
\text { genellikle ilgimi çeker. }\end{array}$ & $136 / 31.2$ & $118 / 27.1$ & $50 / 11.5$ & $44 / 10.1$ & $56 / 12.8$ & $23 / 5.3$ & $9 / 2.1$ & $436 / 100.0$ \\
\hline GÜVENILIIRLİK & $\begin{array}{c}1 \\
\mathrm{n} / \%\end{array}$ & $\begin{array}{c}2 \\
\mathrm{n} / \%\end{array}$ & $\begin{array}{c}3 \\
\mathrm{n} / \% \\
\end{array}$ & $\begin{array}{c}4 \\
\mathrm{n} / \%\end{array}$ & $\begin{array}{c}5 \\
\mathrm{n} / \% \\
\end{array}$ & $\begin{array}{c}6 \\
\mathrm{n} / \% \\
\end{array}$ & $\begin{array}{c}7 \\
\mathrm{n} / \% \\
\end{array}$ & $\begin{array}{c}\text { Toplam } \\
\text { n/\% }\end{array}$ \\
\hline $\begin{array}{l}\text { Reklam kampanyasında vaat } \\
\text { edilen sözler zamanında yerine } \\
\text { getirilir. }\end{array}$ & $65 / 14.9$ & $97 / 22.2$ & $43 / 9.9$ & $131 / 30.0$ & $61 / 14.0$ & $26 / 6.0$ & $13 / 3.0$ & $436 / 100.0$ \\
\hline $\begin{array}{l}\text { Reklamı yapan personel, merak } \\
\text { ettiğim soruları samimi bir } \\
\text { șekilde cevaplandırır. }\end{array}$ & $23 / 5.3$ & $79 / 18.1$ & $35 / 8.0$ & $71 / 16.3$ & $\begin{array}{c}102 / 23 \\
4\end{array}$ & $94 / 21.6$ & $32 / 7.3$ & $436 / 100.0$ \\
\hline $\begin{array}{l}\text { Reklam kampanyasında vaat } \\
\text { edilen hizmet vaat edilen } \\
\text { zamanında yerine getirilir. }\end{array}$ & $39 / 8.9$ & $81 / 18.6$ & $42 / 9.6$ & $122 / 28.0$ & $86 / 19.7$ & $48 / 11.0$ & $18 / 4.1$ & $436 / 100.0$ \\
\hline $\begin{array}{l}\text { Reklam aramalarında konuşmalar } \\
\text { doğru ve eksiksiz bir şekilde kayıt } \\
\text { altına alınmaktadır. }\end{array}$ & $20 / 4.6$ & $23 / 5.3$ & $19 / 4.4$ & $170 / 39.0$ & $45 / 10.3$ & $\begin{array}{c}111 / 25 \\
5\end{array}$ & $48 / 11.0$ & $436 / 100.0$ \\
\hline YETERLİLİK & $\begin{array}{c}1 \\
\mathrm{n} / \%\end{array}$ & $\begin{array}{c}2 \\
\mathrm{n} / \%\end{array}$ & $\begin{array}{c}3 \\
\mathrm{n} / \%\end{array}$ & $\begin{array}{c}4 \\
\mathrm{n} / \%\end{array}$ & $\begin{array}{c}5 \\
\mathrm{n} / \%\end{array}$ & $\begin{array}{c}6 \\
\mathrm{n} / \% \\
\end{array}$ & $\begin{array}{c}7 \\
\mathrm{n} / \% \\
\end{array}$ & $\begin{array}{c}\text { Toplam } \\
\text { n/\% }\end{array}$ \\
\hline $\begin{array}{l}\text { Reklamı yapan personel, reklam } \\
\text { kampanyasının geçerlilik süresi } \\
\text { hakkında bilgi verir. }\end{array}$ & $26 / 6.0$ & $63 / 14.4$ & $42 / 9.6$ & $69 / 15.8$ & $65 / 14.9$ & $\begin{array}{l}134 / 30 \\
7\end{array}$ & $37 / 8.5$ & $436 / 100.0$ \\
\hline $\begin{array}{l}\text { Reklamı yapan personel, hizmeti } \\
\text { mümkün olan en kısa sürede } \\
\text { gerçekleştirir. }\end{array}$ & $37 / 8.5$ & $62 / 14.2$ & $46 / 10.6$ & $79 / 18.1$ & $89 / 20.4$ & $88 / 20.2$ & $35 / 8.0$ & $436 / 100.0$ \\
\hline $\begin{array}{l}\text { Reklamı yapan personel, } \\
\text { müşterilere her zaman yardımcı } \\
\text { olmaya çalıșır. }\end{array}$ & $29 / 6.7$ & $56 / 12.8$ & $39 / 8.9$ & $54 / 12.4$ & $\begin{array}{c}108 / 24 \\
8\end{array}$ & $\begin{array}{c}121 / 27 \\
8\end{array}$ & $29 / 6.7$ & $436 / 100.0$ \\
\hline $\begin{array}{l}\text { Reklamı yapan personel, } \\
\text { müşterilerin her türlü sorusuna } \\
\text { cevap verebilecek bilgi düzeyine } \\
\text { sahiptir. }\end{array}$ & $31 / 7.1$ & $61 / 14.0$ & $44 / 10.1$ & $86 / 19.7$ & $97 / 22.2$ & $84 / 19.3$ & $33 / 7.6$ & $436 / 100.0$ \\
\hline GÜVEN & $\begin{array}{c}1 \\
\mathrm{n} / \%\end{array}$ & $\begin{array}{c}2 \\
\mathrm{n} / \%\end{array}$ & $\begin{array}{c}3 \\
\mathrm{n} / \%\end{array}$ & $\begin{array}{c}4 \\
\mathrm{n} / \%\end{array}$ & $\begin{array}{c}5 \\
\mathrm{n} / \%\end{array}$ & $\begin{array}{c}6 \\
\mathrm{n} / \%\end{array}$ & $\begin{array}{c}7 \\
\mathrm{n} / \% \\
\end{array}$ & $\begin{array}{c}\text { Toplam } \\
\text { n/\% }\end{array}$ \\
\hline $\begin{array}{l}\text { Reklamı yapan personel, } \\
\text { müşterilerde güven duygusu } \\
\text { uyandırır. }\end{array}$ & $60 / 13.8$ & $82 / 18.8$ & $41 / 9.4$ & $72 / 16.5$ & $92 / 21.1$ & $61 / 14.0$ & $28 / 6.4$ & $436 / 100.0$ \\
\hline $\begin{array}{l}\text { Reklamı yapan personel, } \\
\text { müşterilere karşı daima saygılıdır. }\end{array}$ & $10 / 2.3$ & $18 / 4.1$ & $30 / 6.9$ & $32 / 7.3$ & $92 / 21.1$ & $\begin{array}{c}194 / 44 . \\
5\end{array}$ & $60 / 13.8$ & $436 / 100.0$ \\
\hline $\begin{array}{l}\text { Reklam firması müşterilerde } \\
\text { güven duygusu uyandırır. }\end{array}$ & $59 / 13.5$ & $85 / 19.5$ & $34 / 7.8$ & $78 / 17.9$ & $90 / 20.6$ & $61 / 14.0$ & $29 / 6.7$ & $436 / 100.0$ \\
\hline $\begin{array}{l}\text { Reklam kampanyasını satın alan } \\
\text { müşteriler, reklamı yapan } \\
\text { personelin kendi sorularına cevap } \\
\text { verebilecek bilgiye sahip } \\
\text { olduğuna inanırlar. }\end{array}$ & $16 / 3.7$ & $52 / 11.9$ & $28 / 6.4$ & $77 / 17.7$ & $84 / 19.3$ & $\begin{array}{c}138 / 31 \\
7\end{array}$ & $41 / 9.4$ & $436 / 100.0$ \\
\hline EMPATİ & $\begin{array}{c}1 \\
\mathrm{n} / \%\end{array}$ & $\begin{array}{c}2 \\
\mathrm{n} / \%\end{array}$ & $\begin{array}{c}3 \\
\mathrm{n} / \%\end{array}$ & $\begin{array}{c}4 \\
\mathrm{n} / \%\end{array}$ & $\begin{array}{c}5 \\
\mathrm{n} / \% \\
\end{array}$ & $\begin{array}{c}6 \\
\mathrm{n} / \% \\
\end{array}$ & $\begin{array}{c}7 \\
\mathrm{n} / \% \\
\end{array}$ & $\begin{array}{c}\text { Toplam } \\
\mathrm{n} / \%\end{array}$ \\
\hline $\begin{array}{l}\text { Reklamı yapan personel, bana } \\
\text { özel ilgi gösterir. }\end{array}$ & $44 / 10.1$ & $92 / 21.1$ & $32 / 7.3$ & $62 / 14.2$ & $91 / 20.9$ & $98 / 22.5$ & $17 / 3.9$ & $436 / 100.0$ \\
\hline $\begin{array}{l}\text { Reklamı yapan personel, benimle } \\
\text { kişisel olarak ilgilenir. }\end{array}$ & $50 / 11.5$ & $102 / 23.4$ & $27 / 6.2$ & $50 / 11.5$ & $92 / 21.1$ & $99 / 22.7$ & $16 / 3.7$ & $436 / 100.0$ \\
\hline $\begin{array}{l}\text { Reklamı yapan personel, benim } \\
\text { çıarlarımı her șeyden üstün tutar. }\end{array}$ & $168 / 38.5$ & $121 / 27.8$ & $25 / 5.7$ & $55 / 12.6$ & $33 / 7.6$ & $21 / 4.8$ & $13 / 3.0$ & $436 / 100.0$ \\
\hline $\begin{array}{l}\text { Reklamı yapan personel, benim } \\
\text { özel isteklerimi anlar. }\end{array}$ & $93 / 21.3$ & $97 / 22.2$ & $51 / 11.7$ & $62 / 14.2$ & $80 / 18.3$ & $40 / 9.2$ & $13 / 3.0$ & $436 / 100.0$ \\
\hline
\end{tabular}




\begin{tabular}{|l|c|c|c|c|c|c|c|c|}
\hline $\begin{array}{l}\text { Reklam1 yapan personel, } \\
\text { aramaları bana uygun saat } \\
\text { dilimlerinde yapar. }\end{array}$ & $157 / 36.0$ & $119 / 27.3$ & $40 / 9.2$ & $38 / 8.7$ & $42 / 9.6$ & $22 / 5.0$ & $18 / 4.1$ & $436 / 100.0$ \\
\hline
\end{tabular}

(Hiç Katılmıyorum:1; Katılmıyorum:2; Biraz Katılmıyorum:3; Kararsızım:4; Biraz Katılıyorum:5; Katılyyorum:6; Tamamen Katıliyorum:7)

Tablo 3'ün verilerine göre; ankete katılan katılımcıların hizmet kalitesi değişkenlerinden "Fiziksel Varlıklar"a ilişkin ölçeklere katılım düzeyleri incelendiğinde, katılımcıların \%83'ünün reklam personelinin güzel ve düzgün bir ses tonuna sahip olduğunu, yaklaşık \%89'unun ise reklam personelinin konuşmasının nazik olduğunu ifade ettikleri, ancak, katılımciların \%71'inin reklam aramalarının kendilerine uygun zaman dilimlerinde yapılmadığını, \%70'inin ise reklam aramaları yoluyla kendilerine sunulan reklam kampanyalarının ilgilerini çekmediğini belirttikleri görülmektedir. Hizmet kalitesi değişkenlerinden "Güvenilirlik" boyutuna ait ölçekler incelendiğinde, katılımcıların \%47'sinin reklam kampanyasında vaat edilen sözlerin tutulmadığını, \%38'inin ise vaat edilen hizmetlerin vaat edilen zamanda yerine getirilmediğini ifade ettikleri söylenebilir. Hizmet kalitesi değişkenlerinden "Yeterlilik" boyutuna ilişkin ölçekler incelendiğinde, katılımcıların \%60'ının reklam personelinin müşterilere her zaman yardımcı olmaya çalıştığını, \%52'sinin ise personelin sorulan her soruya cevap verebilecek yeterlilikte olduğunu ifade ettikleri görülmektedir. Hizmet kalitesi değişkenlerinden "Güven" boyutuna ilişkin ölçekler incelendiğinde katılımcıların \%80'inin reklam personelinin müşterilere karşı daima saygılı olduğunu, \%61'inin ise reklam personelinin müşteri tarafından sorulan sorulara cevap verebilecek bilgiye sahip olduğunu belirttikleri görülmektedir. Hizmet kalitesi değişkenlerinden "Empati" boyutuna ilişkin ölçeklen incelendiğinde katılımcıların \%72'sinin reklam personelinin müşteri çıkarlarını her şeyden üstün tuttuğunu, \%56'sının reklam personelinin müşterilerin özel isteklerini anlamadığını, \%72,5'sinin ise reklam personelinin reklam aramalarını kendilerine uygun zaman dilimlerinde yapılmadığını belirttikleri görülmektedir. Aşağıdaki bölümde mobil reklamcılıkta algılanan müşteri memnuniyeti değişkenlerine ilişkin tanımlayıcı istatistiklere yer verilmiştir.

\subsection{Katılımcıların Müş̧eri Memnuniyeti Değişkenlerini Algılama Düzeylerine İlişkin Tanımlayıcı İstatistikler}

Algılanan müşteri memnuniyeti düzeyi algılanan değer, algılanan kalite ve müşteri beklentileri olmak üzere üç boyuttan oluşmaktadır. $\mathrm{Bu}$ boyutlardaki iyileşme algılanan müşteri memnuniyeti düzeyini olumlu yönde etkileyecektir. Aşağıdaki tabloda, algılanan müşteri memnuniyetine ilişkin "algılanan kalite", "algılanan değer" ve "müşteri beklentileri" değişkenlerine dair ölçekler ve bu ölçeklere katılım düzeylerine ait veriler yer almaktadır: 
Girişimcilik İnovasyon ve Pazarlama Araştırmaları Dergisi

Y1l:2017, 1(1):39-66
Journal of Research in Entrepreneurship Innovation and Marketing Year:2017, 1(1):39-66

Tablo 4: Müşteri Memnuniyeti Değişkenlerini Algılama Düzeylerine İlişkin Bulgular

\begin{tabular}{|c|c|c|c|c|c|c|c|c|}
\hline ALGILANAN DEĞER & $\begin{array}{c}1 \\
\mathrm{n} / \%\end{array}$ & $\begin{array}{c}2 \\
\mathrm{n} / \% \\
\end{array}$ & $\begin{array}{c}3 \\
\mathrm{n} / \% \\
\end{array}$ & $\begin{array}{c}4 \\
\mathrm{n} / \%\end{array}$ & $\begin{array}{c}5 \\
\mathrm{n} / \% \\
\end{array}$ & $\begin{array}{c}6 \\
\mathrm{n} / \% \\
\end{array}$ & $\begin{array}{c}7 \\
\mathrm{n} / \% \\
\end{array}$ & $\begin{array}{c}\text { Toplam } \\
\mathrm{n} / \%\end{array}$ \\
\hline $\begin{array}{l}\text { Yapılan reklam aramaları, zevkli ve } \\
\text { eğlencelidir. }\end{array}$ & $169 / 38.8$ & $132 / 30.3$ & $36 / 8.3$ & $37 / 8.5$ & $38 / 8.7$ & $15 / 3.4$ & $9 / 2.1$ & $436 / 100.0$ \\
\hline $\begin{array}{l}\text { Yapılan reklam aramaları, } \\
\text { faydalıdır. }\end{array}$ & $105 / 24.1$ & $76 / 17.4$ & $50 / 11.5$ & $60 / 13.8$ & $98 / 22.5$ & $40 / 9.2$ & $7 / 1.6$ & $436 / 100.0$ \\
\hline $\begin{array}{l}\text { Yapılan reklam aramaları, keyif } \\
\text { vericidir. }\end{array}$ & $174 / 39.9$ & $139 / 31.9$ & $30 / 6.9$ & $33 / 7.6$ & $36 / 8.3$ & $18 / 4.1$ & 6.1 .4 & $436 / 100.0$ \\
\hline $\begin{array}{l}\text { Yapılan reklam aramaları ilgi } \\
\text { alanıma, istek ve ihtiyaçlarıma } \\
\text { yöneliktir. }\end{array}$ & $118 / 27.1$ & $110 / 25.2$ & $53 / 12.2$ & $50 / 11.5$ & $67 / 15.4$ & $28 / 6.4$ & $9 / 2.1$ & $436 / 100.0$ \\
\hline $\begin{array}{l}\text { Yapılan reklam aramaları, hizmete } \\
\text { zamanında ulaşabilme açısından iyi } \\
\text { bir kaynaktır. }\end{array}$ & $84 / 19.3$ & $85 / 19.5$ & $37 / 8.5$ & $70 / 16.1$ & $89 / 20.4$ & $58 / 13.3$ & $13 / 3.0$ & $436 / 100.0$ \\
\hline $\begin{array}{l}\text { Yapılan reklam aramaları, } \\
\text { pazarlama etiğine uygun değildir. }\end{array}$ & $18 / 4.1$ & $64 / 14.7$ & $41 / 9.4$ & $136 / 31.2$ & $59 / 13.5$ & $67 / 15.4$ & $51 / 11.7$ & $436 / 100.0$ \\
\hline $\begin{array}{l}\text { Reklam aramaları ile sunulan } \\
\text { reklam kampanyası hizmetlerinden } \\
\text { faydalanmayı hiç düşünmedim. }\end{array}$ & $20 / 4.6$ & $32 / 7.3$ & $40 / 9.2$ & $54 / 12.4$ & $61 / 14.0$ & $108 / 24.8$ & $121 / 27.8$ & $436 / 100.0$ \\
\hline $\begin{array}{l}\text { Reklam aramaları ile sunulan } \\
\text { reklam kampanyası hizmetlerini } \\
\text { dinlemeden geri çeviriyorum. }\end{array}$ & $19 / 4.4$ & $56 / 12.8$ & $35 / 8.0$ & $25 / 5.7$ & $97 / 22.2$ & $97 / 22.2$ & $107 / 24.5$ & $436 / 100.0$ \\
\hline $\begin{array}{l}\text { Rahatsız edici boyutlara ulaşan } \\
\text { reklam aramaları, ilgili firma } \\
\text { üzerinde olumsuz bir alg1 } \\
\text { yaratmaktadır. }\end{array}$ & $8 / 1.8$ & $15 / 3.4$ & $18 / 4.1$ & $25 / 5.7$ & $45 / 10.3$ & $107 / 24.5$ & $218 / 50.0$ & $436 / 100.0$ \\
\hline ALGILANAN KALITE & $\begin{array}{c}1 \\
\mathrm{n} / \%\end{array}$ & $\begin{array}{c}2 \\
\mathrm{n} / \%\end{array}$ & $\begin{array}{c}3 \\
\mathrm{n} / \%\end{array}$ & $\begin{array}{c}4 \\
\mathrm{n} / \%\end{array}$ & $\begin{array}{c}5 \\
\mathrm{n} / \% \\
\end{array}$ & $\begin{array}{c}6 \\
\mathrm{n} / \%\end{array}$ & $\begin{array}{c}7 \\
\mathrm{n} / \% \\
\end{array}$ & $\begin{array}{c}\text { Toplam } \\
\mathrm{n} / \%\end{array}$ \\
\hline $\begin{array}{l}\text { Reklamı yapan personel, hizmet } \\
\text { kalitesi açısından tatmin edicidir. }\end{array}$ & $19 / 4.4$ & $56 / 12.8$ & $23 / 5.3$ & $105 / 24.1$ & $114 / 26.1$ & $96 / 22.0$ & $23 / 5.3$ & $436 / 100.0$ \\
\hline $\begin{array}{l}\text { Reklamı yapan personel, her türlü } \\
\text { soruma cevap verebilecek bilgi } \\
\text { düzeyine sahiptir. }\end{array}$ & $20 / 4.6$ & $56 / 12.8$ & $35 / 8.0$ & $90 / 20.6$ & $106 / 24.3$ & $94 / 21.6$ & $35 / 8.0$ & $436 / 100.0$ \\
\hline $\begin{array}{l}\text { Reklamı yapan personel, ruh halimi } \\
\text { anlayabilmektedir. }\end{array}$ & $38 / 8.7$ & $112 / 25.7$ & $49 / 11.2$ & $86 / 19.7$ & $82 / 18.8$ & $48 / 11.0$ & $21 / 4.8$ & $436 / 100.0$ \\
\hline $\begin{array}{l}\text { Reklamı yapan personel, reklam } \\
\text { kampanyasını günün uygun } \\
\text { saatlerinde yapmaktadır. }\end{array}$ & $97 / 22.2$ & $115 / 26.4$ & $45 / 10.3$ & $37 / 8.5$ & $52 / 11.9$ & $53 / 12.2$ & $37 / 8.5$ & $436 / 100.0$ \\
\hline $\begin{array}{l}\text { Reklamı yapan personel, yeterli } \\
\text { teknik bilgi ve beceri düzeyine } \\
\text { sahiptir. }\end{array}$ & $18 / 4.1$ & $47 / 10.8$ & $51 / 11.7$ & $85 / 19.5$ & $91 / 20.9$ & $103 / 23.6$ & $41 / 9.4$ & $436 / 100.0$ \\
\hline $\begin{array}{l}\text { Reklam aramaları ile sunulan } \\
\text { reklam kampanyası hizmetlerini } \\
\text { gereksiz buluyorum. }\end{array}$ & $11 / 2.5$ & $38 / 8.7$ & $34 / 7.8$ & $50 / 11.5$ & $85 / 19.5$ & $89 / 20.4$ & $129 / 29.6$ & $436 / 100.0$ \\
\hline $\begin{array}{l}\text { Reklam aramaları ile sunulan } \\
\text { reklam kampanyası hizmetlerini } \\
\text { rahatsız edici buluyorum. }\end{array}$ & $11 / 2.5$ & $26 / 6.0$ & $27 / 6.2$ & $40 / 9.2$ & $80 / 18.3$ & $103 / 23.6$ & $149 / 34.2$ & $436 / 100.0$ \\
\hline $\begin{array}{l}\text { Reklam aramaları ile reklam } \\
\text { kampanyasını sunan personelin } \\
\text { tarafima yaptı̆̆ı 1srarlı aramalardan } \\
\text { memnun değilim. }\end{array}$ & $6 / 1.4$ & $7 / 1.6$ & $12 / 2.8$ & $21 / 4.8$ & $30 / 6.9$ & $115 / 26.4$ & $245 / 56.2$ & $436 / 100.0$ \\
\hline MÜŞTERİ BEKLENTİLERİ & $\begin{array}{c}1 \\
\mathrm{n} / \%\end{array}$ & $\begin{array}{c}2 \\
\mathrm{n} / \% \\
\end{array}$ & $\begin{array}{c}3 \\
\mathrm{n} / \%\end{array}$ & $\begin{array}{c}4 \\
\mathrm{n} / \%\end{array}$ & $\begin{array}{c}5 \\
\mathrm{n} / \%\end{array}$ & $\begin{array}{c}6 \\
\mathrm{n} / \%\end{array}$ & $\begin{array}{c}7 \\
\mathrm{n} / \% \\
\end{array}$ & $\begin{array}{c}\text { Toplam } \\
\mathrm{n} / \%\end{array}$ \\
\hline $\begin{array}{l}\text { Reklam aramaları günün uygun } \\
\text { zaman dilimlerinde yapılmalıdır. }\end{array}$ & $12 / 2.8$ & $12 / 2.8$ & $8 / 1.8$ & $10 / 2.3$ & $18 / 4.1$ & $166 / 38.1$ & $210 / 48.2$ & $436 / 100.0$ \\
\hline $\begin{array}{l}\text { Reklam aramaları benim iznim } \\
\text { alınarak yapılmalıdır. }\end{array}$ & $11 / 2.5$ & $6 / 1.4$ & $6 / 1.4$ & $8 / 1.8$ & $22 / 5.0$ & $106 / 24.3$ & $277 / 63.5$ & $436 / 100.0$ \\
\hline $\begin{array}{l}\text { Cevaplamadığım reklam } \\
\text { aramalarında firma, aramada ısrarcı } \\
\text { olmamalıdır. }\end{array}$ & $7 / 1.6$ & $3 / 0.7$ & $2 / 0.5$ & $7 / 1.6$ & $13 / 3.0$ & $96 / 22.0$ & $308 / 70.6$ & $436 / 100.0$ \\
\hline $\begin{array}{l}\text { Reklamı yapan personel/firma } \\
\text { benim çıarlarıma öncelik } \\
\text { vermelidir. }\end{array}$ & $5 / 1.1$ & $12 / 2.8$ & $2 / 0.5$ & $22 / 5.0$ & $34 / 7.8$ & $148 / 33.9$ & $213 / 48.9$ & $436 / 100.0$ \\
\hline $\begin{array}{l}\text { Reklamı yapan personel benim özel } \\
\text { isteklerimi anlamaya çalışmalıdır. }\end{array}$ & $7 / 1.6$ & $12 / 2.8$ & $10 / 2.3$ & $14 / 3.2$ & $38 / 8.7$ & $162 / 37.2$ & $193 / 44.3$ & $436 / 100.0$ \\
\hline $\begin{array}{l}\text { Reklamı yapan personel, her türlü } \\
\text { soruma cevap verebilecek } \\
\text { yeterlilikte olmalıdır. }\end{array}$ & $2 / 0.5$ & $7 / 1.6$ & $3 / 0.7$ & $11 / 2.5$ & $14 / 3.2$ & $141 / 32.3$ & $258 / 59.2$ & $436 / 100.0$ \\
\hline
\end{tabular}




\begin{tabular}{|l|c|c|c|c|c|c|c|c|}
\hline $\begin{array}{l}\text { Reklamı yapan personel, benim } \\
\text { bilgi düzeyimi dikkate alarak bilgi } \\
\text { vermelidir. }\end{array}$ & $4 / 0.9$ & $14 / 3.2$ & $5 / 1.1$ & $12 / 2.8$ & $22 / 5.0$ & $179 / 41.1$ & $200 / 45.9$ & $436 / 100.0$ \\
\hline $\begin{array}{l}\text { Reklamı yapan personel, benim ruh } \\
\text { halimi anlayabilmelidir. }\end{array}$ & $13 / 3.0$ & $32 / 7.3$ & $19 / 4.4$ & $41 / 9.4$ & $77 / 17.7$ & $120 / 27.5$ & $134 / 30.7$ & $436 / 100.0$ \\
\hline $\begin{array}{l}\text { Reklamı yapan personel, bende } \\
\text { güven duygusu uyandırmalıdır. }\end{array}$ & $3 / 0.7$ & $3 / 0.7$ & $2 / 0.5$ & $16 / 3.7$ & $15 / 3.4$ & $166 / 38.1$ & $231 / 53.0$ & $436 / 100.0$ \\
\hline $\begin{array}{l}\text { Reklamı yapan personel, } \\
\text { kampanyayı mümkün olduğunca } \\
\text { kısa ve öz şekilde anlatabilmelidir. }\end{array}$ & $6 / 1.4$ & $5 / 1.1$ & $5 / 1.1$ & $6 / 1.4$ & $17 / 3.9$ & $143 / 32.8$ & $254 / 58.3$ & $436 / 100.0$ \\
\hline $\begin{array}{l}\text { Reklam aramalarında sunulan } \\
\text { reklam kampanyaları benim ihtiyaç } \\
\text { ve özelliklerime uygun olmalıdır. }\end{array}$ & $6 / 1.4$ & $7 / 1.6$ & $7 / 1.6$ & $19 / 4.4$ & $21 / 4.8$ & $170 / 39.0$ & $206 / 47.2$ & $436 / 100.0$ \\
\hline $\begin{array}{l}\text { Reklam aramalarını sunan firma, } \\
\text { bende güven duygusu } \\
\text { uyandırmalıdır. }\end{array}$ & $3 / 0.7$ & $3 / 0.7$ & $2 / 0.5$ & $16 / 3.7$ & $15 / 3.4$ & $166 / 38.1$ & $231 / 53.0$ & $436 / 100.0$ \\
\hline $\begin{array}{l}\text { Reklam aramalarında sunulan } \\
\text { reklam kampanyaları benim için } \\
\text { yönlendirici ve yararlı olmalıdır. }\end{array}$ & $6 / 1.4$ & $4 / 0.9$ & $5 / 1.1$ & $18 / 4.1$ & $18 / 4.1$ & $175 / 40.1$ & $210 / 48.2$ & $436 / 100.0$ \\
\hline
\end{tabular}

Tablo 4'ün verileri incelendiğinde, algllanan müşteri memnuniyeti değişkenlerinden "Algılanan Değer" boyutuna dair ölçekler incelendiğinde katılımcıların \%78'inin reklam aramalarını zevkli ve eğlenceli bulmadıkları, \%79'unun ise reklam aramalarının keyif verici olduğuna inanmadıkları görülmektedir. Katılımcıların \%65'inin yapılan reklam aramalarının ilgi alanına, istek ve ihtiyaçlarına yönelik olmadığını, \%67'sinin reklam aramaları ile sunulan reklam kampanyalarından faydalanmayı hiç düşünmediklerini ifade ettikleri görülmektedir. Katılımcıların \%69'u yapılan reklam aramalarını dinlemeden geri çevirdiğini, \%85'i ise rahatsız edici boyutlara ulaşan reklam aramalarının, firma üzerinde olumsuz bir alg1 yarattığını ifade etmişlerdir. Algılanan müşteri memnuniyeti değişkenlerinden "Algılanan Kalite" boyutuna dair ölçekler incelendiğinde katılımcıların \%54'ünün reklam personelini hizmet kalitesi açısından tatmin edici buldukları ve personelin sorulan her türlü soruya cevap verebilecek yeterlilikte bilgi ve beceri düzeyine sahip olduğuna inandıkları, ancak katılımcıların \%70'i reklam aramaları ile sunulan reklam kampanyası hizmetlerini gereksiz, \%76'sı ise reklam aramaları ile sunulan reklam kampanyası hizmetlerini rahatsız edici bulmaktadır. Katılımc1ların \% $\% 90$ ' 1 ise ısrarla yapılan reklam aramalarından memnun olmadığını ifade etmişlerdir. Algılanan müşteri memnuniyeti değişkenlerinden "Müşteri Beklentileri” boyutuna ilişkin ölçekler incelendiğinde katılımcıların \%91'inin reklam aramalarının günün uygun zaman dilimlerinde yapılmasını, \%88'inin reklam aramalarının kendi izinleri dâhilinde gerçekleştirilmesini ve \%96'sının ise, cevaplanmayan reklam aramalarında firmaların ısrarcı olmaması gerektiğini ifade ettikleri görülmektedir. Katılımcıların \%91'i firmaların müşteri çıkarlarına öncelik vermesini ve müşteri özel isteklerini anlaması gerektiğini ifade ettikleri, \%95'inin, personelin sorulan her türlü soruya, cevap verebilecek yeterlilikte olması gerektiğini, \%92'sinin müşterilerin bilgi düzeyi gözetilerek reklam hizmeti sunulması gerektiğini, yaklaşık \%76'sının ise reklam yapan personelin, müşterinin ruh halini anlayarak hizmeti vermesi gerektiğini belirttikleri görülmektedir. Katılımcıların \%91'i reklam kampanyalarının müşteri ihtiyaç ve özelliklerine yönelik olması gerektiğini, \%92'si ise reklam kampanyalarının müşteri için yararlı ve yönlendirici olması gerektiğini düşünmektedirler. Katılımcıların \%95'i reklam kampanyalarının reklam aramaları sırasında mümkün olduğunca kısa ve öz bir şekilde aktarılması gerektiğini, firmaların ve reklam personelinin kendilerinde güven duygusu uyandırması gerektiğini vurgulamışlardır. Aşağıdaki bölümlerde hizmet kalitesi ve müşteri memnuniyetine ilişkin değişkenler ile mobil reklamcılıkta müşteri memnuniyeti arasındaki ilişkilere dair analizler yer almaktadır. 


\subsection{Mobil Reklamcılıkta Hizmet Kalitesi Değişkenleri ile Müşteri Memnuniyeti İlişkisine Dair Bulgular}

Mobil reklamcılık kapsamında hizmet kalitesi değişkenleri ile müşteri memnuniyeti ilişkisinin analiz edilmesinde Çoklu Doğrusal Regresyon Modeli kullanılmıştır. Analiz sonucu belirlenen modele ilişkin bulgular aşağıdaki tablolarda yer almaktadır.

Tablo 5: Mobil Reklamcılıkta Hizmet Kalitesi Değişkenleri İle Müşteri Memnuniyeti İlişkisine Dair Model Özeti

\begin{tabular}{|c|c|c|c|c|}
\hline Model & $\mathrm{R}$ & $\mathrm{R}^{2}$ & Düzeltilmiş $\mathrm{R}^{2}$ & $\begin{array}{c}\text { Tahminlerdeki Standart } \\
\text { Hata }\end{array}$ \\
\hline 1 &, $643^{\mathrm{a}}$ &, 413 &, 394 & 1,384 \\
\hline
\end{tabular}

a Bağımsız Değişkenleri: Empati, Güvenilirlik, Fiziksel Varlıklar, Yeterlilik, Güven.

Bağımlı Değişken: Cevabınız evet ise ne kadar memnun kaldınız?

Tablo 5, hizmet kalitesi değişkenleri ile mobil reklamcılıkta müşteri memnuniyeti ilişkisine dair model özetini içermektedir. Modelde empati, güvenilirlik, fiziksel varlıklar, yeterlilik ve güven olmak üzere beş hizmet kalitesi boyutu bir arada yer almaktadır. $\mathrm{R}^{2}$, bağımsız değişkenin bağımlı değişkendeki değişimi açıklama gücünü göstermektedir. Modelde görüldüğü üzere bağımsız değişkenler, bağımlı değişkendeki değişimin \%41,3'ünü açıklamaktadır. Modelin bir bütün olarak anlamlı olup olmadığı Varyans analizi ile test edilmiştir. Analize dair veriler Tablo 6.'da yer almaktadir.

Tablo 6: Hizmet Kalitesi Değişkenleri İle Müşteri Memnuniyeti İlişkisine Dair Anova Testi (Varyans Analizi)

\begin{tabular}{|c|c|c|c|c|c|}
\multicolumn{2}{c|}{ Anova $^{\mathrm{t}}$} \\
\hline Model & $\begin{array}{c}\text { Karelerin } \\
\text { Toplamı }\end{array}$ & $\begin{array}{c}\text { Serbestlik } \\
\text { Derecesi }\end{array}$ & $\begin{array}{c}\text { Ortalamanın } \\
\text { Karesi }\end{array}$ & F & $\begin{array}{c}\text { Anlamlılık } \\
\text { Düzeyi }\end{array}$ \\
\hline Regresyon & 201,094 & 5 & 40,219 & 20,983 &, $000^{\mathrm{a}}$ \\
Hata & 285,590 & 149 & 1,917 & & \\
Toplam & 486,684 & 154 & & \\
\hline
\end{tabular}

a Bağımsız Değişkenleri: Empati, Güvenilirlik, Fiziksel Varlıklar, Yeterlilik, Güven. Bağımlı Değişken: Cevabınız evet ise ne kadar memnun kaldınız?

Tablo 6. incelendiğinde bağımsız değişkene dair F testi sonucunun $\% 95$ güven aralığında ve $\mathrm{P}<0.05$ hata yapma düzeyinde anlamlı olmasından dolayı, modelin bir bütün olarak her düzeyde anlamlı olduğu söylenebilir.

Modelin tahmini sonucu elde edilen parametre değerleri ve bunlara ilişkin t ve Sigma değerleri Tablo 7'de gösterilmiştir. 
Tablo 7: Katsayılar Tablosu

\begin{tabular}{|c|c|c|c|c|c|}
\hline \multirow{2}{*}{ Model } & \multicolumn{2}{|c|}{$\begin{array}{c}\text { Standardize Edilmemiş } \\
\text { Katsayılar }\end{array}$} & Standart Hata & \multirow{2}{*}{ Sigma } \\
\cline { 2 - 4 } & $\mathrm{B}$ & Standart Hata & Beta & $\mathrm{t}$ & \\
\hline \multirow{2}{*}{ Sabit } &,- 359 &, 499 & & & \\
Fiziksel Varlıklar &, 130 &, 151 &, 080 &, 720 &, 473 \\
Güvenilirlik &, 334 &, 120 &, 260 & 2,775 &, 390 \\
Yeterlilik &, 015 &, 138 &, 012 &, 110 &, 006 \\
Güven &, 269 &, 156 &, 193 & 1,727 &, 086 \\
Empati &, 271 &, 107 &, 218 & 2,528 &, 012 \\
& & & & \\
\hline
\end{tabular}

Tablo 7'ye göre her bir bağımsız değişkene ait Sigma değerleri sırasıyla Fiziksel Varlıklar için 0,390; Güvenilirlik için 0,006; Yeterlilik için 0,913; Güven için 0,086 ve Empati için 0,012'dir. Buna göre çalışma amacına uygun olarak geliştirilen hipotezlerden, Güvenilirlik boyutuna ilişkin Hla: "Mobil reklamcılıkta müşteri hizmetleri kalitesinin güvenilirlik düzeyi ile mobil reklamcllıkta müşteri memnuniyeti arasında anlamlı bir ilişki vardır" ve Empati boyutuna ilişkin H1d: "Mobil reklamcllıkta müşteri hizmetleri kalitesinin empati düzeyi ile mobil reklamcılıkta müşteri memnuniyeti arasında anlamlı bir ilişki vardır" hipotezleri \% 95 güven aralığında ve $\mathrm{P}<0.05$ anlamlılık düzeyinde kabul edilmiş olup; Güven boyutuna ilişkin $H 1 b$ : "Mobil reklamcılıkta müşteri hizmetleri kalitesinin güven düzeyi ile mobil reklamcılıkta müşteri memnuniyeti arasında anlaml bir ilişki vardır", Yeterlilik boyutuna ilişkin H1c: "Mobil reklamcllıkta müşteri hizmetleri kalitesinin yeterlilik düzeyi ile mobil reklamcıllkta müşteri memnuniyeti arasında anlamlı bir ilişki vardır" ve Fiziksel Varlıklar boyutuna ilişkin Hle: "Mobil reklamcllıta müşteri hizmetleri kalitesinin fiziksel varlıklar düzeyi ile mobil reklamcılıkta müşteri memnuniyeti arasında anlamlı bir ilişki vardır" hipotezleri reddedilmiştir. Bu bağlamda, H1: "Mobil reklamcılıkta müşteri hizmetleri kalitesi düzeyi ile mobil reklamcılıkta müsteri memnuniyeti arasında anlamlı bir ilişki vardır” hipotezinin kısmen kabul edildiği söylenebilir.

Tablo 7'de standardize edilmiş katsayılar başlığı altında yer alan Beta katsayıları, bağımsız değişkenin önem sırasını göstermektedir. Buna göre \%26 ile en yüksek Beta değerine sahip değişken olan "Güvenilirlik”, göreli olarak en önemli bağımsız değişkendir. Bu durumda mobil reklamcılıkta müşteri memnuniyeti düzeyini belirleyen en önemli hizmet kalitesi değişkenlerinden biri olduğu söylenebilir.

\subsection{Mobil Reklamcılıkta Algılanan Müşteri Memnuniyeti Değişkenleri İle Müşsteri Memnuniyeti İlişkisine Dair Bulgular}

Mobil reklamcılık kapsamında algılanan müşteri memnuniyeti değişkenleri ile müşteri memnuniyeti arasında ilişki olup olmadığını test eden çoklu doğrusal regresyon modeli aşağıdaki tablolarda yer almaktadır. 
Tablo 8: Mobil Reklamcılıkta Algılanan Müşteri Memnuniyeti Değişkenleri İle Müşteri Memnuniyeti İlişkisine Dair Model Özeti

\begin{tabular}{|c|c|c|c|c|}
\hline Model & $\mathrm{R}$ & $\mathrm{R}^{2}$ & Düzeltilmiş $\mathrm{R}^{2}$ & $\begin{array}{c}\text { Tahminlerdeki } \\
\text { Standart Hata }\end{array}$ \\
\hline 1 &, $438^{\mathrm{a}}$ &, 192 &, 176 & 1,614 \\
\hline
\end{tabular}

a Bağımsız Değişkenleri: Algılanan Değer, Müşteri Beklentileri, Algılanan Kalite Bağımlı Değişken: Cevabınız evet ise ne kadar memnun kaldınız?

Tablo 8'de yer alan modelde $\mathrm{R}^{2}$, bağımsız değişkenin bağımlı değişkendeki değişimi açıklama gücünü göstermektedir. Modelde görüldüğü üzere bağımsız değişkenler, bağımlı değişkendeki değişimin \%41,3'ünü açıklamaktadır.

Tablo 9: Mobil Reklamcılıkta Algılanan Müşteri Memnuniyeti Değişkenleri İle Müşteri Memnuniyeti İlişkisine Dair Anova Testi

Anova $^{\mathrm{t}}$

\begin{tabular}{|c|c|c|c|c|c|}
\hline Model & $\begin{array}{c}\text { Karelerin } \\
\text { Toplamı }\end{array}$ & $\begin{array}{c}\text { Serbestlik } \\
\text { Derecesi }\end{array}$ & $\begin{array}{c}\text { Ortalamanin } \\
\text { Karesi }\end{array}$ & F & $\begin{array}{c}\text { Anlamlılik } \\
\text { Düzeyi }\end{array}$ \\
\hline Regresyon & 93,475 & 3 & 31,158 & 11,965 &, $000^{\mathrm{a}}$ \\
Hata & 393,209 & 151 & 2,604 & & \\
Toplam & 486,684 & 154 & & & \\
\hline
\end{tabular}

a Bağımsız Değişkenleri: Algılanan Değer, Müşteri Beklentileri, Algılanan Kalite Bağımlı Değişken: Cevabınız evet ise ne kadar memnun kaldınız?

Tablo 9 incelendiğinde bağımsız değişkene dair $\mathrm{F}$ testi sonucunun $\% 95$ güven aralığında ve $\mathrm{P}<0.05$ hata yapma düzeyinde anlamlı olmasından dolayı, modelin bir bütün olarak her düzeyde anlamlı olduğu söylenebilir.

Modelin tahmini sonucu elde edilen parametre değerleri ve bunlara ilişkin t ve Sigma değerleri Tablo 10'da gösterilmiştir.

Tablo 10: Katsayılar Tablosu

\begin{tabular}{|c|c|c|c|c|c|}
\hline \multirow{2}{*}{ Model } & \multicolumn{2}{|c|}{$\begin{array}{c}\text { Standardize } \\
\text { Edilmemiş Katsayılar }\end{array}$} & Standart Hata & \multirow{2}{*}{ Sig. } \\
\cline { 2 - 4 } & B & Standart Hata & Beta & & \\
\hline Sabit &,- 268 & 1,017 & &,- 264 &, 792 \\
Müşteri Beklentileri &, 083 &, 152 &, 042 &, 547 &, 585 \\
Algılanan Kalite &, 395 &, 177 &, 215 & 2,237 &, 027 \\
Algilanan Değer &, 474 &, 172 &, 259 & 2,762 &, 006 \\
\hline
\end{tabular}


Tablo 10'a göre her bir bağımsız değişkene ait Sigma değerleri sırasıyla Müşteri Beklentileri için 0,585; Algılanan Kalite için 0,027 ve Algılanan Değer için 0,006'dır. Buna göre çalışma amacına uygun olarak geliştirilen hipotezlerden, Algılanan Değer boyutu için geliştirilen H2a: "Algllanan müşteri memnuniyetinin algllanan değer düzeyi ile mobil reklamcılıkta müşteri memnuniyeti arasında anlamlı bir ilişki vardır" ve Algılanan Kalite boyutu için geliştirilen H2b: "Algllanan müşteri memnuniyetinin algllanan kalite düzeyi ile müşteri memnuniyeti arasında anlamlı bir ilişki vardır" hipotezleri, \%95 güven aralığında ve $\mathrm{P}<0.05$ anlamlılık düzeyinde kabul edilmiş olup; Müşteri Beklentileri boyutuna ilişsin H2c: "Algllanan müşteri memnuniyetinin müşteri beklentileri düzeyi ile müşteri memnuniyeti arasında anlamlı bir ilişki vardır" hipotezi reddedilmiştir. Bu bağlamda H2: "Algılanan müşteri memnuniyeti düzeyi ile mobil reklamcılıkta müşteri memnuniyeti arasında anlamlı bir ilişki vardır” hipotezinin kabul edildiği söylenebilir.

Tablo 10'da standardize edilmiş katsayılar başlığı altında yer alan Beta katsayıları, bağımsız değişkenin önem sırasını göstermektedir. Buna göre \%25,9 ile en yüksek Beta değerine sahip değişken olan "Algılanan Değer", göreli olarak en önemli bağımsız değişkendir. Bu durumda mobil reklamcılıkta müşteri memnuniyeti düzeyini belirleyen en önemli algılanan müşteri memnuniyeti değişkeninin algılanan değer olduğu söylenebilir. Mobil reklamcılıkta algılanan değer arttıkça müşteri memnuniyeti düzeyinin de artabileceği ifade edilebilir. \%95 güven aralığında ve $\mathrm{P}<0.05$ anlamlılık düzeyinde kabul ve reddedilen hipotezler Tablo 11'de gösterilmiştir.

Tablo 11: $\mathrm{P}<0.05$ Anlamlılık Düzeyinde Kabul ve Reddedilen Hipotezler

\begin{tabular}{|l|c|}
\hline \multicolumn{1}{|c|}{ Hipotezler } & $\begin{array}{c}\text { P<0.05 Anlamlılık } \\
\text { Düzeyinde Kabul/Red }\end{array}$ \\
\hline $\begin{array}{l}\text { H1: Mobil reklamcılıkta müşteri hizmetleri kalitesi düzeyi ile mobil } \\
\text { reklamcılıkta müşteri memnuniyeti arasında anlamlı bir ilişki vardır. }\end{array}$ & Kabul \\
\hline $\begin{array}{l}\text { H1a: Mobil reklamcılıkta müşteri hizmetleri kalitesinin güvenilirlik düzeyi ile } \\
\text { mobil reklamcılıkta müşteri memnuniyeti arasında anlamlı bir ilişki vardır. }\end{array}$ & Kabul \\
\hline $\begin{array}{l}\text { H1b: Mobil reklamcılıkta müşteri hizmetleri kalitesinin güven düzeyi ile } \\
\text { mobil reklamcılıkta müşteri memnuniyeti arasında anlamlı bir ilişki vardır. }\end{array}$ & Red \\
\hline $\begin{array}{l}\text { H1c: Mobil reklamcılıkta müşteri hizmetleri kalitesinin yeterlilik düzeyi ile } \\
\text { mobil reklamcılıkta müşteri memnuniyeti arasında anlamlı bir ilişki vardır. }\end{array}$ & Red \\
\hline $\begin{array}{l}\text { H1d: Mobil reklamcı̈lıta müşteri hizmetleri kalitesinin empati düzeyi ile } \\
\text { mobil reklamcılıkta müşteri memnuniyeti arasında anlamlı bir ilişki vardır. }\end{array}$ & Kabul \\
\hline $\begin{array}{l}\text { H1e: Mobil reklamcıllkta müşteri hizmetleri kalitesinin fiziksel varlıklar } \\
\text { düzeyi ile mobil reklamcılıkta müşteri memnuniyeti arasında anlamlı bir ilişki } \\
\text { vardır. }\end{array}$ & Red \\
\hline $\begin{array}{l}\text { H2: Algılanan müşteri memnuniyeti düzeyi ile mobil reklamcılıkta müşteri } \\
\text { memnuniyeti arasında anlamlı bir ilişki vardır. }\end{array}$ & Kabul \\
\hline $\begin{array}{l}\text { H2a: Algılanan müşteri memnuniyetinin algılanan değer düzeyi ile mobil } \\
\text { reklamcılıkta müşteri memnuniyeti arasında anlamlı bir ilişki vardır. }\end{array}$ & Kabul \\
\hline $\begin{array}{l}\text { H2b: Algılanan müşteri memnuniyetinin algılanan kalite düzeyi ile müşteri } \\
\text { memnuniyeti arasında anlamlı bir ilişki vardır. }\end{array}$ & Kabul \\
\hline $\begin{array}{l}\text { H2c: Algılanan müşteri memnuniyetinin müşteri beklentileri düzeyi ile } \\
\text { müşteri memnuniyeti arasında anlamlı bir ilişki vardır. }\end{array}$ & Red \\
\hline
\end{tabular}




\section{Sonuç ve Öneriler}

Günümüzde bireylerin tüketim algılarında meydana gelen değişimle birlikte, firmaların sundukları ürün ve hizmetlere karşı çok daha sorgulayan bir tüketici yapısı meydana gelmiştir. Firmalar artık, bir mal ya da hizmeti olduğu gibi kabullenen müşterilere değil, talep ettiği mal ya da hizmet hakkında daha çok bilgi isteyen, onu sorgulayan, kıyaslayan ve tercihlerinde başkalarına danışma ihtiyacı duyan müşterilere hizmet etmek durumundadırlar. Müşterilerin gittikçe bilinçlendiği ve isteklerindeki artış ve çeşitlilik göz önüne alındığında, modern pazarlamada asıl amaç kaliteli hizmet sunarak müşteri memnuniyetini kazanmak olmuştur. Mobil teknolojide yaşanan gelişmelere bağlı olarak mobil araçların pazarlama faaliyetleri içerisinde yer almasıyla birlikte firmalar yer ve zaman kısıtları olmadan müşterilerine ulaşabilmektedirler. Mobil reklamcılıkta firma ile müşteri arasında kurulan ilişki, hizmet kalitesini ve buna bağlı olarak müşteri memnuniyetini doğrudan etkilemektedir.

Çalışmada, mobil reklamcılıkta bireysel müşteri hizmetleri olarak adlandırdığımız sesli reklam hizmetlerinin kalitesi ile müşteri memnuniyeti ilişkisine dair çeşitli bulgular elde edilmiştir.

Tüketiciler, reklam personelinin düzgün konuşma şeklinin ses tonunun ve nazik konuşmasının reklam aramalarının kalitesini etkilediğini düşünmektedirler. Kaba bir üslupla ve yüksek bir ses tonuyla gerçekleştirilen reklam aramalarının kaliteli bir hizmet olduğu ve müşteri memnuniyeti sağlayacağ1 düşünülemez. Firmaların, müşterileriyle etkin bir iletişim sağlayabilmek için ürün ve hizmetlerini müşterilerine tanıtan personellerine iletişim ve sunum eğitimleri vermeleri önem taşımaktadır.

Bireyler, ilgilenmedikleri, ihtiyaç duymadıkları ve kendilerinde merak uyandırmayan ürün ve hizmetleri içeren reklamları almak istememektedirler. Firmaların bu durumu dikkate almaları ve müşterilerinin yaşam tarzı, eğitim ve kültür seviyesi gibi müşteri profilini ortaya koyan özellikleri hakkında bilgi edinerek müşterilerinde ilgi uyandırabilecek ve onların istek ve beklentilerine hitap edecek reklam hizmetleri sunmaları gerekmektedir.

Günlük yaşamda bireylerin, aktif bir çalışma temposuna ve yoğun sosyal ilişkilere sahip olmaları nedeniyle her an cep telefonları üzerinden reklam hizmeti almaları mümkün değildir. Tüketiciler, günün uygun zaman dilimlerinde yapılmayan ve bezdirici sıklıkta tekrar eden reklam aramalarından rahatsızlık duymaktadırlar. Özellikle ilgi duyulmayan ve ihtiyaç hissedilmeyen bir ürün ya da hizmetle ilgili bir reklamı müsait olunmayan bir zaman dilimi içerisinde almak, bıkkınlığa neden olmaktadır. Mesai saatleri içerisinde ya da tatil günlerinde yapılan reklam aramaları bireyleri huzursuz etmektedir. Bu açıdan firmalar, müşterilerinin çalışma ve sosyal hayatı hakkında bilgiler edinerek, reklam aramalarını uygun zaman dilimlerinde gerçekleştirmelidirler. Çalışan nüfus içerisinde yer alan tüketiciler için mesai ve mola saatleri dışında, eğitim-öğretim sınıfı içinde yer alan tüketiciler için aramaların eğitimöğretim saatleri dışında yapılması reklam hizmetinin gerçekleştirilme zamanı açısından örnek teşkil etmektedir. Aramaların gerçekleştirilme zamanının yanında, arama süresi de önemlidir. Reklam aramalarının kısa ve öz biçimde gerçekleştirilmesi bireylerin değerli zamanlarına saygı göstermek açısından gereklidir.

Reklam aramalarının, genellikle günün uygun olmayan zaman dilimlerinde ve bezdirici sıklıkta yapılması, gereğinden uzun sürmesi, çoğunlukla tüketicilerin istek, ihtiyaç ve beklentilerine yönelik olmaması ve personel-müşteri, firma-müşteri arasında güven ilişkisinin kurulamaması gibi nedenlerle reklam aramaları zevkli ve eğlenceli görülmemekte, tüketiciler reklam aramalarından faydalanmayı düşünmemektedirler. Tüketicilerin büyük bir çoğunluğu, 
reklam aramalarının daha içeriğini öğrenmeden gelen çağrıları geri çevirmekte ve reklam aramalarını gereksiz görmektedirler.

Zamanlı zamansız aramaların gerçekleştirilmesi ve aramaların rahatsız edici şekilde 1srarla yapılması, sadece reklam hizmetinin kalitesini olumsuz etkilememektedir. Kat1lımciların büyük çoğunluğuna göre rahatsız edici boyutlara ulaşan reklam aramaları, ilgili firma üzerinde olumsuz bir alg1 yaratmaktadır.

Bireylerin bireysel müşteri hizmet kalitesi çerçevesinde beklenti içinde oldukları başka bir husus da reklam aramaları sırasında müşteriye verilen sözlerin, söz verilen zamanda yerine getirilmesidir. Tüketiciler, reklam personeli ve firmaya güvendikleri takdirde ürün ve hizmet talebinde bulunacaklardır. $\mathrm{Bu}$ nedenle firma ile müşteri arasında güven ilişkisi kurulmalı, tüketici çıkarlarının ve beklentilerinin ön planda tutulduğu bir hizmet sunulmalıdır. Bunun yanı sıra reklam personelinin, müşteri sorunlarına daima çözüm yolu üretebilecek ve teknik meselelere hâkim olabilecek bilgi ve yeterlilikte olması gerekmektedir.

Tüketicilerin homojen bir yapıya sahip olmamaları nedeniyle sunulan her reklam hizmetinin her müşteri için aynı şekilde karşılık bulması düşünülemez. Her tüketici farklı bir karaktere, ruh haline ve eğitim-kültür seviyesine sahiptir. Bu farklılıkların değerlendirilerek sunulan reklam aramaları tüketicilerde olumlu bir karşılık bulacaktır. $\mathrm{Bu}$ nedenle reklam hizmetlerinin içeriği ve sunulma biçimi belirlenirken bu heterojen yapının dikkate alınması gerekmektedir.

Çalışmada bireysel müşteri hizmetleri olarak ifade ettiğimiz reklam aramaları, kamuoyunda "taciz aramaları" olarak nitelendirilmektedir. Rahatsız edici boyutlara ulaşan reklam mesajlarına ve reklam aramalarına yönelik şikâyetler son yıllarda artmış durumdadır. Tüketici izni dışında gerçekleştirilen reklam aramalarının engellenmesine yönelik yapılan hukuksal çalışmalar kamuoyunda ilgiyle takip edilmektedir.

\section{Kaynakça}

Acuner, Şebnem Akın. (2001). Müşteri İlişkilerinde Hareket Noktası: Müşteri Memnuniyeti ve Ölçümü, Milli Prodüktivite Yayınları No: 655, Ankara.

Aksu, Murat. (2010). Hizmet Kalitesinin Bir Unsuru Olarak Atmosferin Müşteri Sadakati Üzerine Etkisi: Bozcaada'daki Otellerde Konaklayan Yerli Turistler Üzerinde Bir Araştırma, Balıkesir Üniversitesi Sosyal Bilimler Enstitüsü, Doktora Tezi.

Alakavuk, Elif Deniz. (2007). Hizmet Kalitesi Değerlendirme Ölçeği: SERQUAL Hizmet Kalitesi Kavramlar, Yaklaşımlar ve Uygulamalar, Detay Yayıncılık, Ankara.

Altunışık, R. Özdemir, Ş. ve Torlak Ö. (2007). Pazarlamaya Giriş, Sakarya Yayıncılık. İstanbul:

Anderson, Eugene W. (1994), "Cross-Category Variation in Customer Satisfaction and Retention," Marketing Letters, 5 (1), pp.19-30.

Arslan, K. ve Arslan, P. (2012). Mobil Pazarlama, Papatya Yayıncılık, İstanbul.

Bae, Young Han, (2012). Three Essays On The Customer Satisfaction-Customer Loyalty Asscociation, University of Iowa, Doktora tezi.

Balcı, Z. Y. (2010). Türkiye'deki Kahve Zincir(ler)inde Tüketici Alışkanlıklarının Belirlenmesi ve Müşteri Memnuniyetinin İncelenmesi, Marmara Üniversitesi Sosyal Bilimler Enstitüsü, Yüksek Lisans Tezi. 
Barutçu, S. Öztürk Göl M. (2009). "Mobil Reklamlar ve Mobil Reklam Araçlarına Yönelik Tutumlar", KMU İ̈BF Dergisi, (17), ss. 24-41.

Bilir, A. (2010), Katılım Bankalarında Müşteri Memnuniyetinin Belirlenmesi Üzerinde Bir Araştırma, Çukurova Üniversitesi Sosyal Bilimler Enstitüsü, Yüksek Lisans Tezi.

Can, Eda. (2010). Bankacılık Sektöründe Müşteri Memnuniyeti, Akdeniz Üniversitesi Sosyal Bilimler Enstitüsü, Yüksek Lisans Tezi.

Coşar, F. (2006). Hizmet Sektöründe Müşteri Memnuniyetinin Ölçülmesi ve Bir Leasing Şirketinde Uygulama, Marmara Üniversitesi Sosyal Bilimler Enstitüsü, Yüksek Lisans Tezi.

Çakır, S. ve Eğinli, A. (2010). Memnun Çalışanlar, Memnun Müşteriler, Detay Yayıncılık, Ankara.

Çatı, K. ve Baydaş, A. (2008). Hizmet Pazarlaması ve Hizmet Kalitesi, Asil Yayın Dağıtım, Ankara.

Çelik, P. (2012). GSM Operatörlerinin Hizmet Kalitesinin Değerlendirilmesi: KTÜ İktisadi ve İdari Bilimler Fakültesi Örneği, Karadeniz Teknik Üniversitesi Sosyal Bilimler Enstitüsü, Yüksek Lisans Tezi.

Çınar, T. (2007), İşletmelerde Müşteri Hizmeti ve Müşteri Memnuniyeti ile Farklı Bankalar ve Bölgeler için Müşteri Memnuniyetini Belirlemeye Yönelik Uygulama, Aydın Menderes Üniversitesi Sosyal Bilimler Enstitüsü, Yüksek Lisans Tezi.

Dağtaş, B. ve Becerikli S., Birsen Ö., Dağtaş, E. ve Çelik, Y. (2013). Medya ve Reklam, Anadolu Üniversitesi Yayınları, Eskişehir.

De Reyck, B; Degraeve, Z. (2003). "Broadcast Schedulling For Mobile Advertising" Operations Research, 51(4), pp.509-517.

Değermen, Al. (2006). Hizmet Ürünlerinde Kalite, Müşteri Tatmini ve Sadakati, Türkmen Kitabevi: İstanbul.

Dominici, G. \& Guzzo, R. (2010). “Customer Satisfaction In The Hotel Industry: A Case Study From Sicily”, International Journal of Marketing Studies, 2(2), November, pp.3-12.

Eleren, A. ve Kılıç, B. (2007). “Turizm Sektöründe SERVQUAL Analizi İle Hizmet Kalitesinin Ölçülmesi ve Bir Termal Otelde Uygulama”, Afyon Kocatepe Üniversitesi İ̈BF Dergisi, 9(1), ss.235-263.

Ertürk, K. \& Kıyak, C. (2011). "Müşteri Memnuniyeti Artırma Aracı Olarak Halkla İlişkilere Maslow'un İhtiyaçlar Hiyerarşisi Penceresinden Bakmak", Gazi Üniversitesi İletişim Fakültesi Dergisi, 32, ss.127-150.

Eru, O. (2013). Süpermarket Sektöründeki Mobil Pazarlama Uygulamalarının Tüketici Davranışlarına Etkisi: Aydın Örneği, Adnan Menderes Üniversitesi Sosyal Bilimler Enstitüsü, Yüksek Lisans Tezi.

Fuller, P. (2005). “Why Spam Doesn't Have to Happen on Mobile Devices," Mobile Marketing ssociation, mmaglobal.com/modules/wfsection/article.php?articleid=44 (Erişim Tarihi 04/05/2015).

Grönroos (1982). "Strategic Management and Marketing in Service Sector”, Swedish School of Economics and Business Administration. Helsinki, Finland. 
Güllülü, U., Erciş, A., Ünal, S. ve Yapraklı, Ş. (2008). Sağlık Hizmetlerinde Müşteri Memnuniyeti, Detay Yayıncilik, Ankara.

Gürbüz, E. (2005). "Devlet ve Özel İlköğretim Okullarında Hizmet Kalitesinin Karşılaştırılmasına İlişkin Bir Araştırma”, Gazi Üniversitesi İIBF Dergisi, 7(1), ss.97119.

Güzeler, A. (2010). Mobil Pazarlama ve SMS (Kısa Mesaj) İle Yapılan Reklam ve Kampanyaların Tüketici Davranışı Üzerindeki Etkilerine Yönelik Bir Uygulama: Şanlıurfa Örneği, Harran Üniversitesi Sosyal Bilimler Enstitüsü, Yüksek Lisans Tezi.

Kenzhebayeva, A. (2012). Turizm Sektöründe Hizmet Kalitesi: Türkiye ve Kazakistan'daki Termal Otel İşletmelerinde Karşılaştırmalı Bir Araştırma, Gazi Üniversitesi Eğitim Bilimleri Enstitüsü, Yüksek Lisans Tezi.

Kıraç, S. (2012). SMS Reklamlarına Yönelik Tüketici Tutumları Oluşturan Faktörler,Bahçeşehir Üniversitesi Sosyal Bilimler Enstitüsü, Yüksek Lisans Tezi.

Koç, Ü. (2007). Hizmet Kalitesi Algılamalarının Müşteri Bağlılığına Etkisi ve Bir Uygulama, Kocaeli Üniversitesi Sosyal Bilimler Enstitüsü, Yüksek Lisans Tezi.

Koçoğlu, M. (2009). Hizmet Kalitesinin Müşteri Sadakati Üzerindeki Etkisi ve Beş Yıldızlı Bir Otel İşletmesinde Uygulama, Düzce Üniversitesi Sosyal Bilimler Enstitüsü, Yüksek Lisans Tezi.

LeBlanc, G. (1992). Factors affecting customer evaluation of service quality travel agencies: an investigation of customer perceptions. Journal of Travel Research 30 (4): 10-16.

Lehtinen, J.R. and Lehtinen, U. (1982). "Service quality: a study of quality dimensions", unpublished Working Paper, Service Management Institute, Helsinki.

Lewis, Robert C. and Booms, B. H. (1983). "The Marketing Aspects of Service Quality," in Emerging Perspectives on Services Marketing, L. Berry, G. Shostack, and G. Upah, eds., Chicago: American Marketing, 99-107.

Naktiyok, A. Küçük, O. (2003), "İşgören ve Müşteri Tatmini, İşgören Tatmininin Müşteri Tatmini Üzerine Etkileri: Ampirik Bir Değerlendirme", Atatürk Üniversitesi İ̈BF Dergisi, (1-2), ss.225-243.

Okumuş, A. ve Duygun A. (2008). "Eğitim Hizmetlerinin Pazarlanmasında Hizmet Kalitesinin Ölçümü ve Algılanan Hizmet Kalitesi ile Öğrenci Memnuniyeti Arasındaki İlişki”,Anadolu Üniversitesi Sosyal Bilimler Dergisi, 8(2), ss.20-38.

Oliver, R. (1980). "A Cognitive Model of the Antecedents and Consequences of Satisfaction Decisions", Journal of Marketing, 17 (November), pp.460-469.

Özgüven, N. (2013). Mobil Pazarlama ve Mobil Reklam, Dora Basım Yayın Dağıtım, Bursa.

Özveren, S. (2010). Müşteri Memnuniyeti ve Hizmet Kalitesi İlişkileri: Mersin İlindeki 4 ve 5 Yıldızlar Oteller Örneği, Mersin Üniversitesi Sosyal Bilimler Enstitüsü, Yüksek Lisans Tezi.

Parasuraman, A., Zeithaml, V.A. and Berry, L.L. (1985). "A conceptual model of service quality and its implication", Journal of Marketing, 49, Fall, pp. 41-50.

Rasila, H. M. (2009). "From B-To-B Service Quality To Customer Experience", Journal of Service Science, 2(1), 35-44. 
Sasser, W. Earl, Olsen, R. P. and Wyckoff D. D. (1978). Management of Service Operations: text, cases and readings, Hardvard University, Graduate School of Business Administration, Allyn and Bacon, Boston.

Subaşı, L. (2010). Hizmet Kalitesi, Kurumsal İmaj ve Güvenin Kurumsal Müşteri Sadakatine Etkisi: Katılım Bankacılığında Bir Uygulama, Gebze İleri teknoloji Enstitüsü, Sosyal Bilimler Enstitüsü, Yüksek Lisans Tezi.

Tak, B. (1998). "Hem Müşteri Odaklı Hem de Müşteri Odağı Olmaya Geçiş: Müşteri Değeri Araştırmaları", 7. Ulusal kalite kongresi, tebliğ ve özgeçmişler.

Tavmergen, P. (2002). Doğrudan Pazarlama Yönetimi: Kavramlar, İlkeler ve Uygulama, Seçkin Yayınları, İstanbul.

Türkyılmaz, A. ve Coşkun Ö. (2003). "Ulusal Müşteri Memnuniyeti İndeksleri”, 3. Üretim Araştırmaları Sempozyumu.

Törtop, İ. C. (2008). “Müşteri Memnuniyeti İçin 7 İpucu”, Kaynak: http://www.plusvalue.net/ yayinlarimiz/Musteri_Memnuniyeti/Musteri_Memnuniyeti_Icin_7_Ipucu, Erişim Tarihi: 02.03.2015).

Yalçın, F. (2012). İnternet Pazarlamasında Müşteri Memnuniyeti: Günün Fırsatları Üzerinde Bir Uygulama, Atılım Üniversitesi Sosyal Bilimler Enstitüsü, Yüksek Lisans Tezi.

http://www.mmaglobal.com/ (Erişim Tarihi: 17/05/2015). 


\section{EXTENDED ABSTRACT}

\section{Customer Satisfaction in Mobile Advertising: A Case Study on Social Media Users}

With the development of mobile technology leading to the use of mobile tools in advertising channels, firms' efforts to provide quality service and customer satisfaction have also improved. While technology developed on one hand, the wishes, needs, and expectations of customers have also changed on the other. Nowadays, consumers demand quality products and services that can satisfy them the most. Today's competitive conditions require consumers to were be reached without time and space limitations. Mobil vehicles provide to reach consumers directly, without time and space limitations. Firms to used this advertising channel effectively and efficiently in the frame of marketing ethic and obtain opportunities to provide better quality service and to provide customer satisfaction.

In this study, threads related to advertising, service quality, and customer contentment are examined. In order to demonstrate the correlation between individual customer service quality and customer contentment, the questionnaire has been distributed among Facebook, Twitter, and Linkedin users. The survey data was processed on statistical package software and the findings have been evaluated.

In the study, multiple linear regression analysis was used to test the relationship between service quality and perceived customer satisfaction variables with customer satisfaction of mobile advertising. Variables of service quality were determined as Reliability, Trust, Competence, Empathy, and Physical Assets. Perceived customer satisfaction variables consisted of perceived value, perceived quality, and customer expectations.

In mobile advertising, service quality variables and customer satisfaction relationship were analysed using Multiple Linear Regression Model. According to the analysis results, the Reliability and Empathy from service quality variables were found to have a relationship with customer satisfaction at $\mathrm{p}<0.05$ significance level. However, the Physical Assets, Trust and Competence from service quality variables were not found to have a relationship with customer satisfaction at $\mathrm{p}<0.05$ significance level. Accordingly, H1a and H1d were accepted, H1b, H1c, and H1e were rejected.

In mobile advertising, the Multiple Linear Regression Model was used to determine whether there is a relationship between perceived customer satisfaction variables and customer satisfaction. According to the analysis results, the perceived value and perceived quality from perceived customer satisfaction variables were found to have a relationship with customer satisfaction at $\mathrm{p}<0,05$ significance level. However, the customer expectations from perceived customer satisfaction variables were not found to have a relationship with customer satisfaction at $\mathrm{p}<0,05$ significance level. Accordingly, $\mathrm{H} 2 \mathrm{a}$ and $\mathrm{H} 2 \mathrm{~b}$ were accepted, $\mathrm{H} 2 \mathrm{c}$ was rejected. 